\title{
التقنيات التعليمية بين الواقع والطموح (دراسة مقارنة)
}

الباحث : امير محم علي رسول السعدي

ماجستير ط.ت العلوم العامة / جامعة كربلاء

Ameeralsadiiu@yahoo.com
م.م. عمر فلاح عواد الجنابي

ماجستير ط.ت العلوم العامة / تربية بابل عرابل

Omarfalah73@yahoo.com

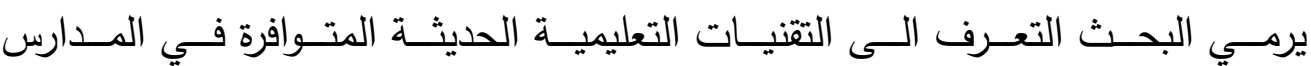

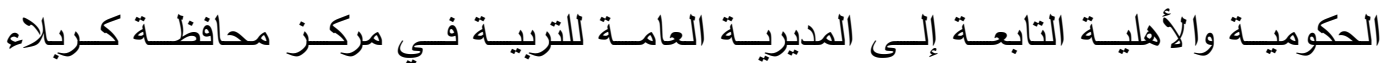

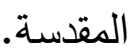

ولغرض التحقق من هدف البحث جرب صياغة الأسئلة الآتية :

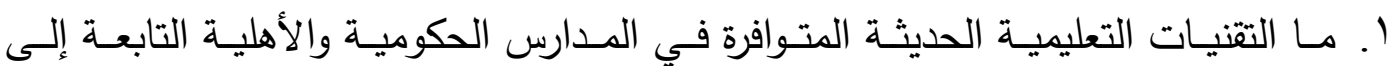
المديرية العامة للتربية في مركز محافظة كربلاء المقدسة؟

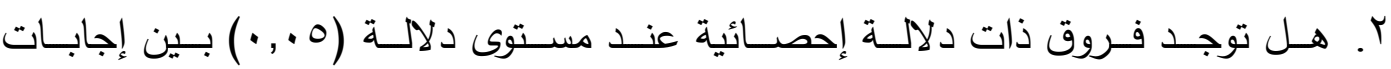
أفراد العينة تبعاً لمتغير الجنس؟ ترجد

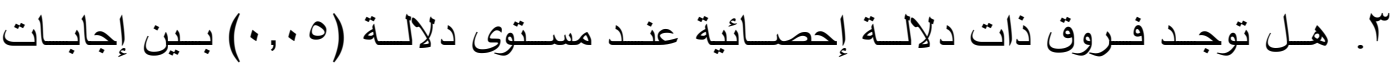
أفراد العينة تبعاً لمتغير المرحلة الدراسية؟

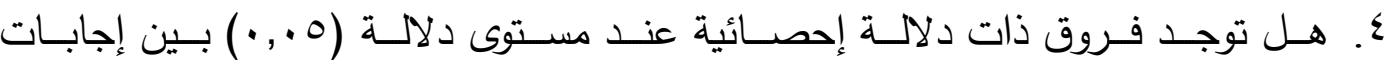
أفراد العينة تبعاً لمتغير نوع الدارسة؟ تروف دالاه

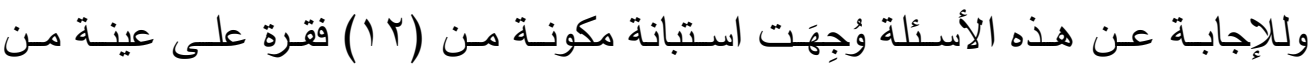

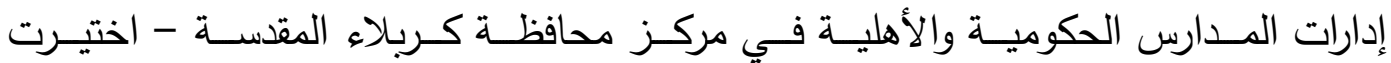
بالطريقة الطبقية - بلغت (إ) (إدارة مدرسية بواقع (V0) مديراً و(T) مديرةً.

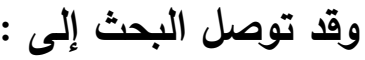

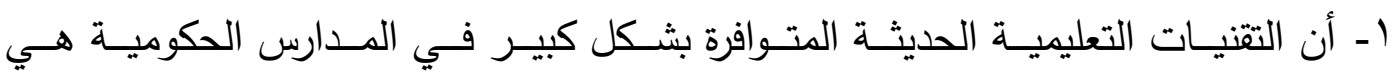
(مسـجل كاسـيت، آلــة تصــوير، مجهـر ) أمـــا التقنيـات التعليميـة الحديثـة المتـوافرة

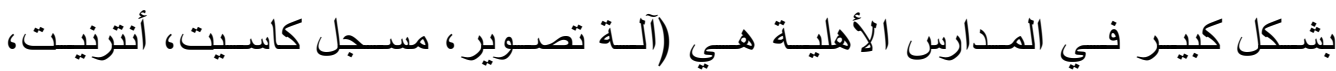
شاشة ذكية) r- أن التقنيـات التعليميـة الحديثـة المتـوافرة بثـكل قليـل فـي الـــارس الحكوميـة فهـي

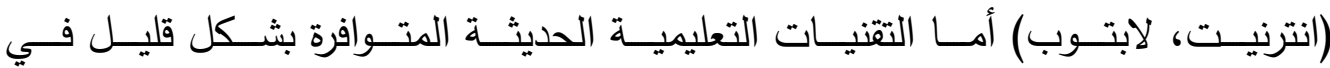

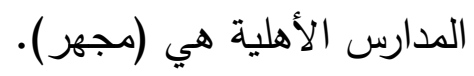




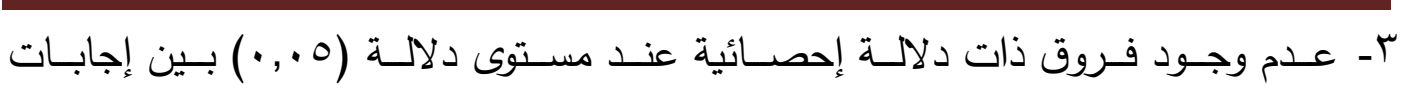
أفراد العينة تبعاً لمتغير الجنس.

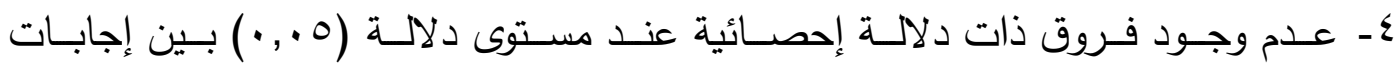
أفراد العينة تبعاً لمتغير المرحلة الدراسية.

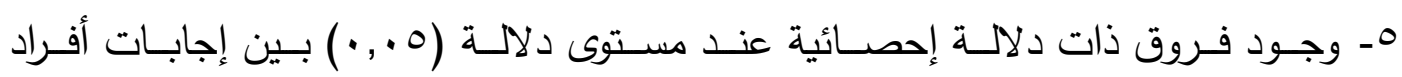

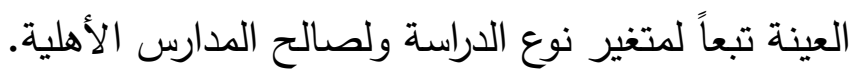
كلمات مفتاحية (Key Words): التقنيات التعليمية، الواقع، الطموح مشكلة البحث (Research Problem):

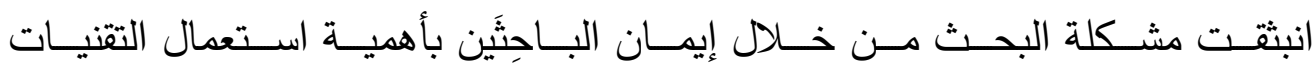

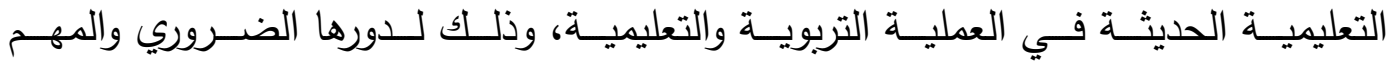

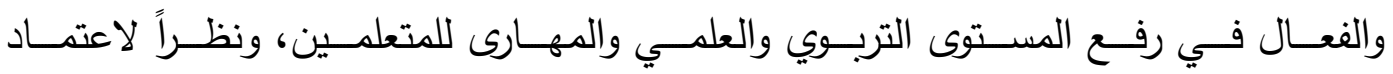

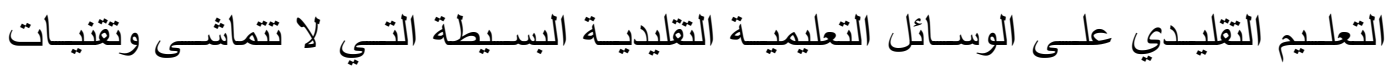

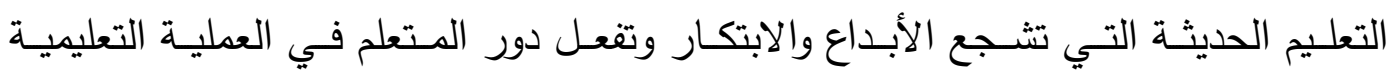

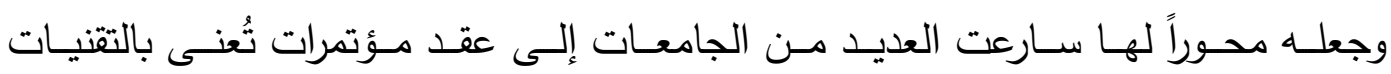
التعليمية لها لها من أثر بالغ وواضح في رفع المستوى التربوي والعلمي للمتعلمين.

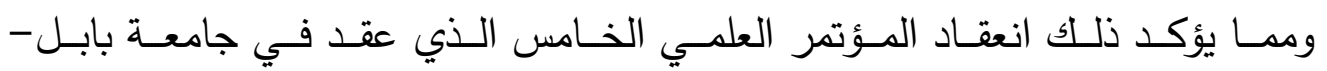

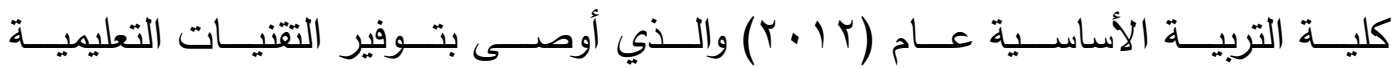

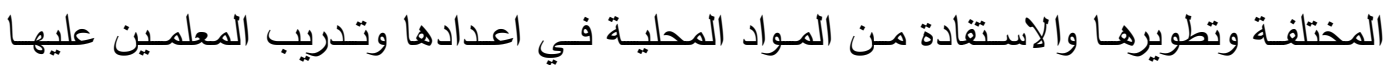

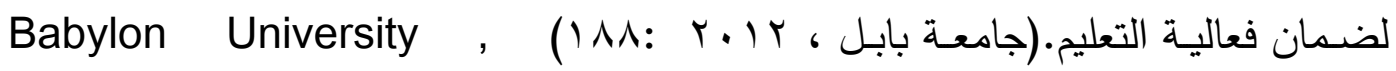
(2012 : 188)

وبذلك تتمثل مشكلة البحث في الإجابة عن السؤال الآتي:

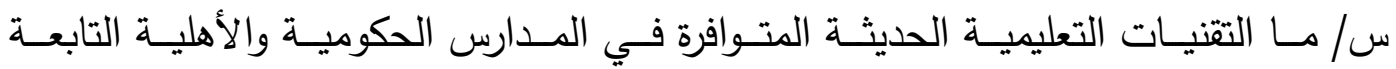
الى مديرية تربية كربلاء المقدسة؟ أهمية البحث (Research Importance):

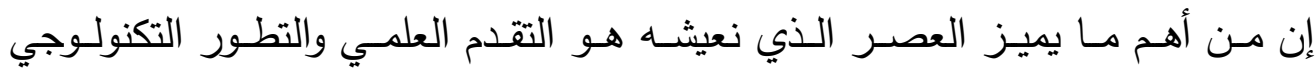

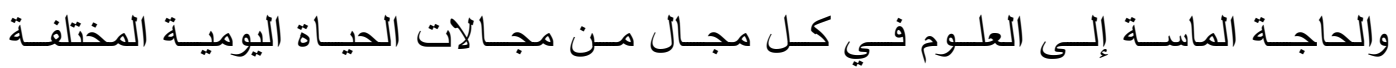

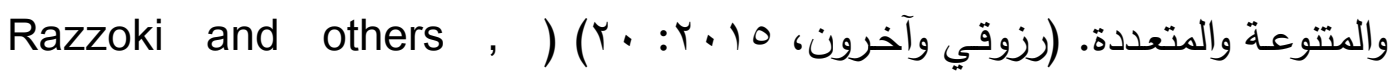
(2015: 20

هذا مـا جعل العمليـة التعليميـة تقف أمسام تحديات كبيـرة تدعوها إلى إعـادة النظر

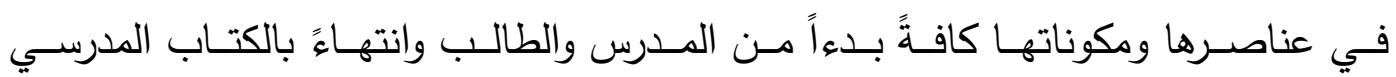


والتقنيـات التعليميـة، لـذلك أصــبح علـى العمليـة التعليميـة ضــرورة تطـوير منظومتهـا لمسـايرة ومواكبـة هـذا التقـدم العلمـي والتطـور التكنولـوجي والحاجـة الماسـة إلـى العلـوم

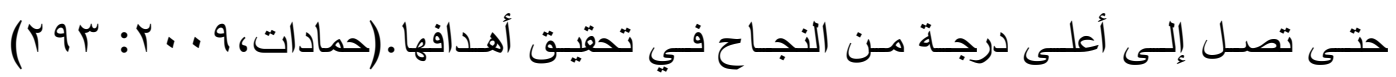

(Hammadat , $2009: 293$ )

فالتربيـة جـزه مسن الثقافـة واداة في حفظهـا و وإعـادة انتاجهـا فـي أفضـل صــورة ،

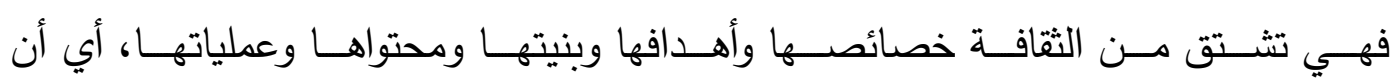
التربيـة تتشـكل مـن الثقافـة وتقوم بوظائفهـا في تحقيـق أهـدافها لتعيـد أنتـاج هـذه الثقافـة

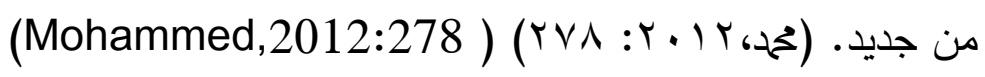

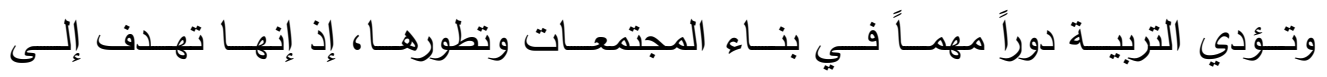
أحـداث تغيـرات مرغوبـة في سـلوك الإنسـان وتتميتهـه وتوجيهــهـ نحـو خدمـة مجتمعـه، فهي العمليـة التي تـؤدي إلى إحـداث تغييـر شـامل في سـلوك الفـرد الفكـري والوجـداني

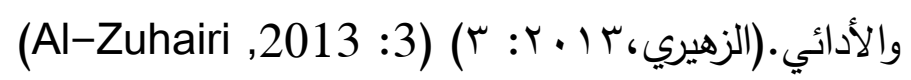

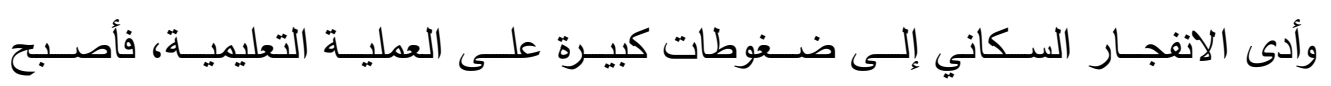
واجبـاً على المؤسسـات التعليميـة أن تواكـب هـذا العـدد الهائـل مــن المتعلمـين الـذين يقبلـون على التعلـيم، ممــا جعـل تلـك المؤسسـات تضـيق بهـم لأسـباب ماديـة منهـا: نقـص المبـاني، والتكــاليف الباهظــة للتعلـيم، وقلــة التجهيـزات الماديـة، وقلــة المعلمـين

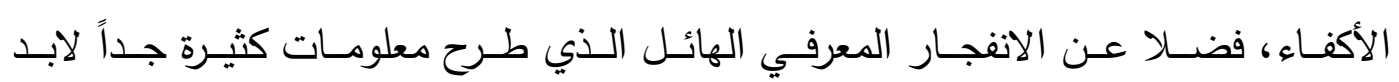
للمـتعلم مـن تناولهـا فـي وقـت قصـير حتى يسـاير ويواكـب المعلومـات الجديـدة التـي

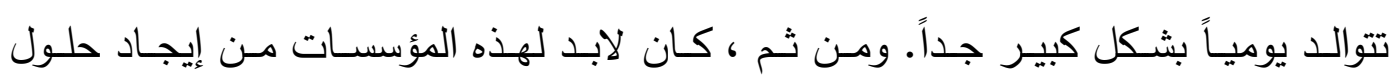

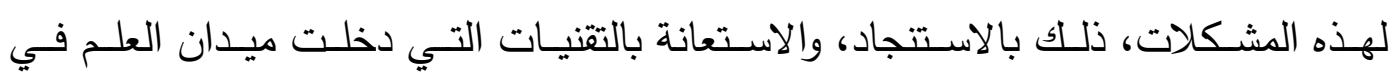

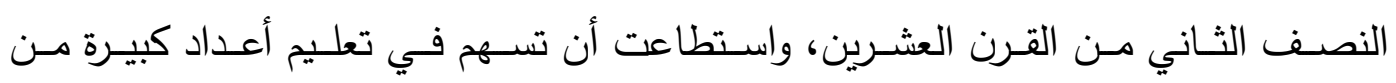
المتعلمـين في صـفوف مزدحمـة وعالجـت مشـكلة الزيـادة الهائلــة في المعرفـة الإنسـانية

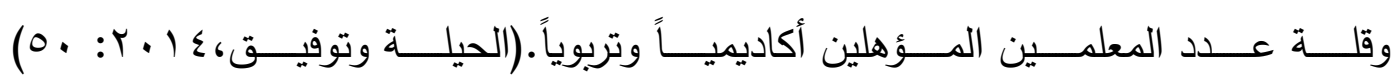

(Al-Hailah and Tawfiq, $2014: 50$ ) لـذلك تضـافرت جهـود الكثيـر مـن البـاحثين المختصـين فـي مجـال التربيـة والتعلـيم

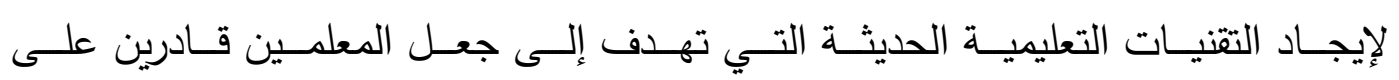
إيصـال المعرفـة أو المعلومـة إلى متعلميهم بأقـل تكلفـة وجهــ وبمـا يـتلاءم مـع مهـاراتهم

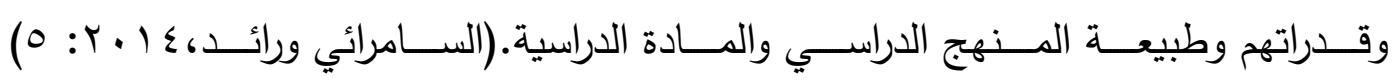

(Samurai and Raed ,2014:5) 


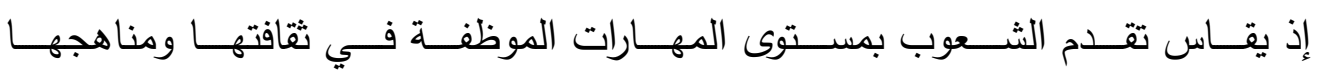

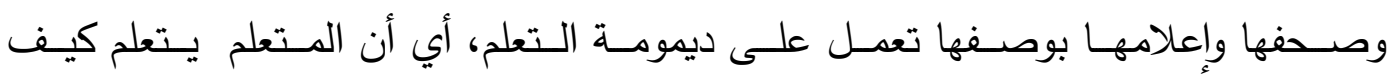

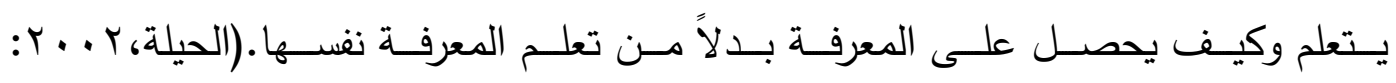

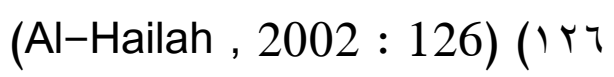

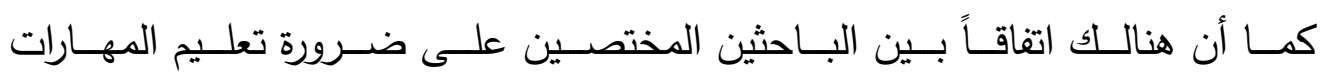

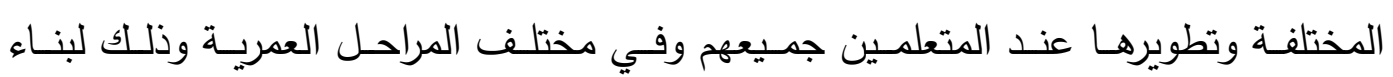

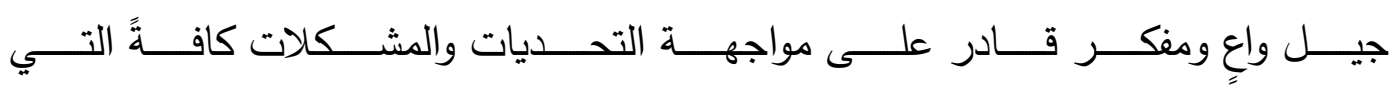

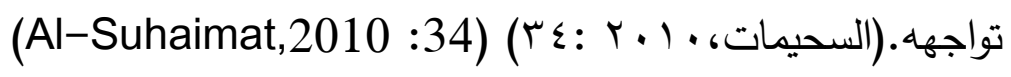
وتكمن أهمية البحث في الآتي:

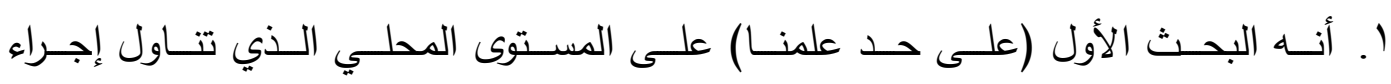

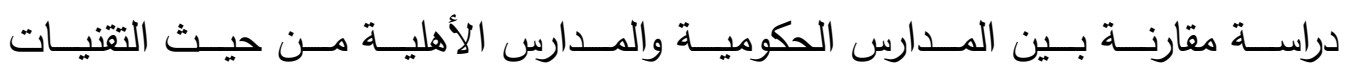
التعليمية الحديثة.

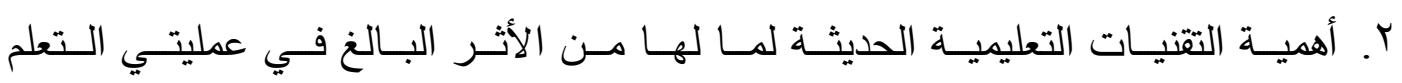
والتعليم ورفع المستوى التزبوي والعلمي للمتعلمين.

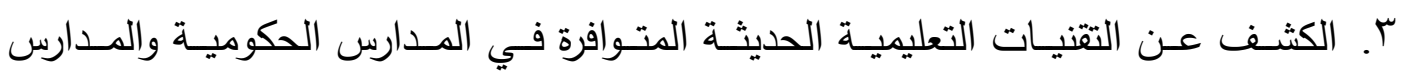
الأهلية. ع. قد يشكل هذا البحث نواة لبحوث أُخر .

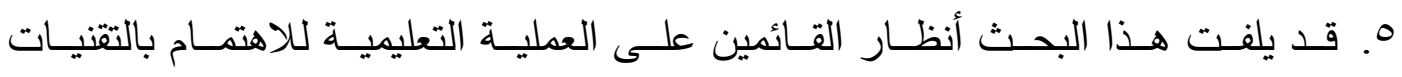
التعليمية الحديثة.

\section{هدف البحث (Research Aim):}

التعـرف الـى التقنيـات التعليميـة الحديثـة المتـوافرة في المـــارس الحكوميـة والأهليـة التابعة إلى المديرية العامة للتربية في مركز محافظة كربلاء المقدسة. أسئلة البحث (Research Questions):

ولغرض التحقق من هدف البحث جرب صياغة الأسئلة الآتية :

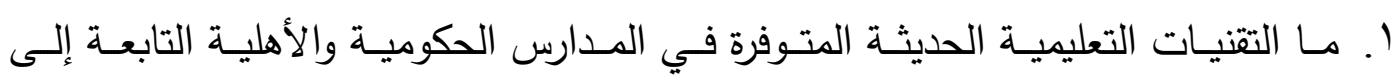
المديرية العامة للتربية في محافظة كربلاء المقدسة؟ بلفية

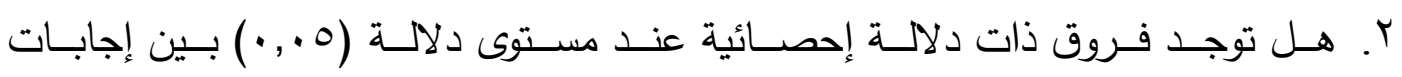

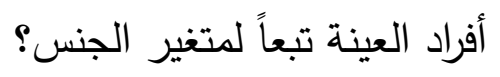

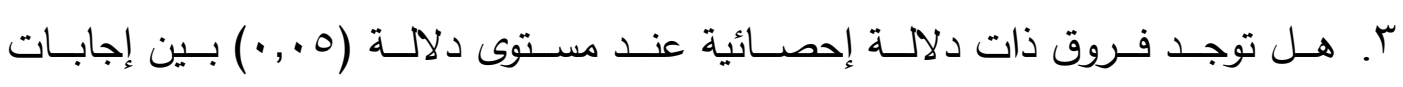
أفراد العينة تبعاً لمتغير المرحلة الدراسية؟ درد دلاته 


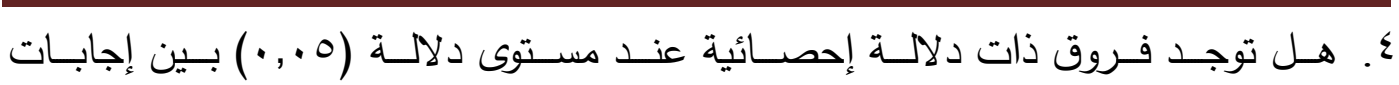
أفراد العينة تبعاً لمتغير نوع الدارسة؟ دونج

التقنيات التعليمية (Educational Techniques):

اشـتقت كلمـة تكنولوجيـا (Technology) التـي عربـت الـى تقنيـات، مـن الكلمـة

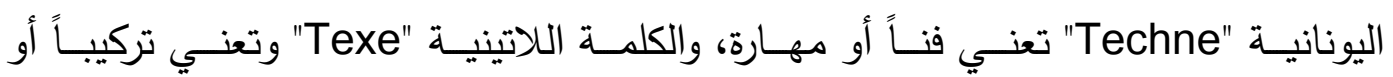

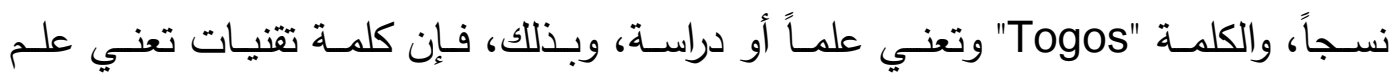

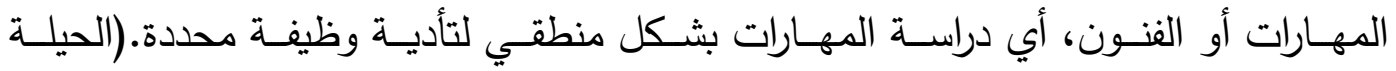

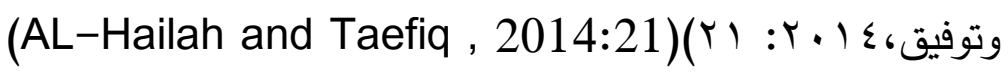

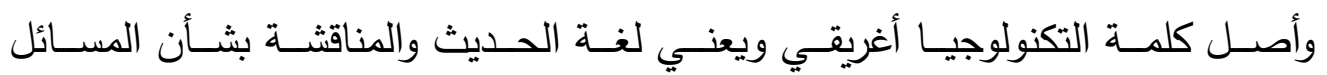

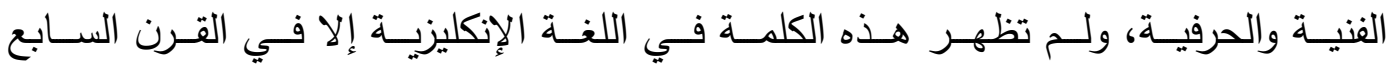

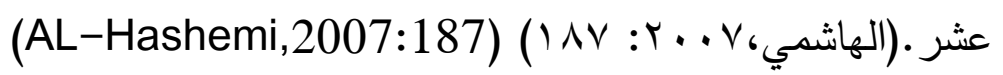

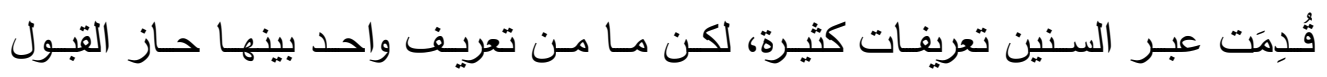

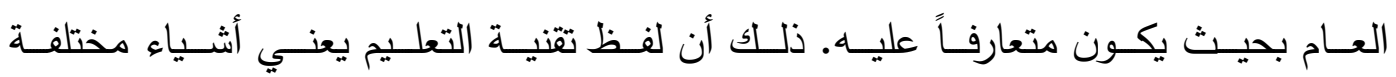

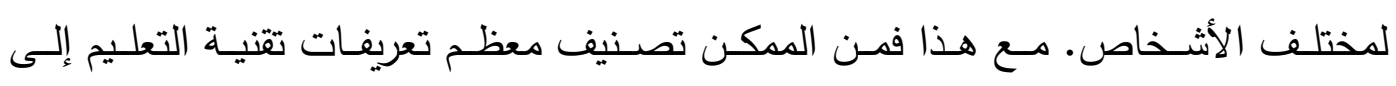

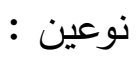
- - أحدهما يعد تقنيـة التعليم معادلـة لمجموعـة معينـة مـن الوسـائط التعليميـة التي كثيراً ما يشار إليها بلفظ الأجهزة السمعية البصرية.

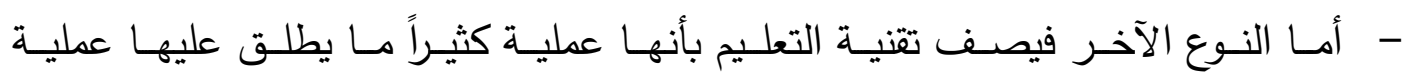
مدخل النظم.

ولعل أفضـل مثال لتوضيح هذين النوعين مـن التعريفـات هـو ذلك الذي يتضــنه

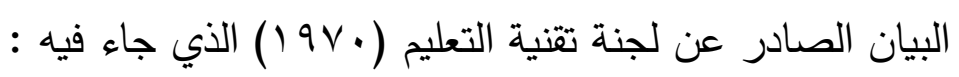

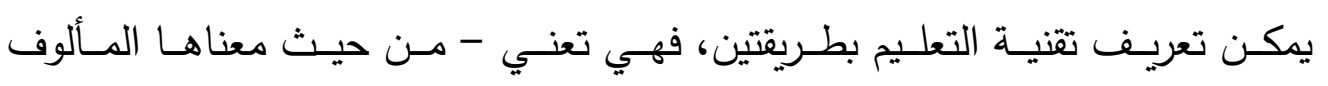

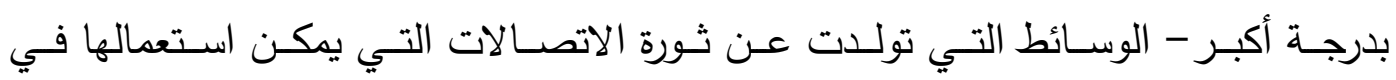

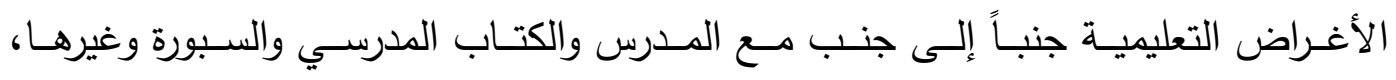

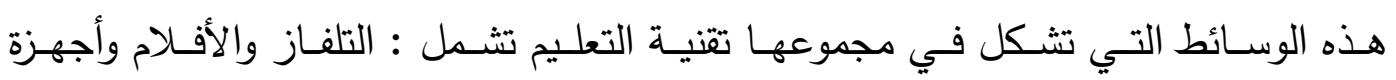
العرض والحواسيب وغير ذلك من الأجهزة والمعدات والبرامج.

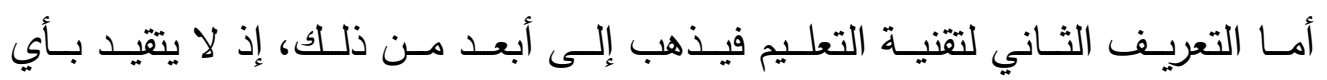

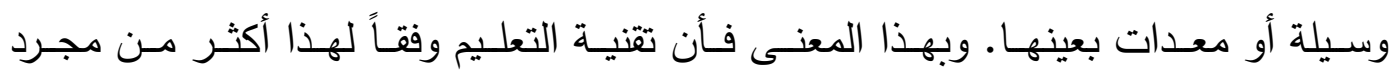

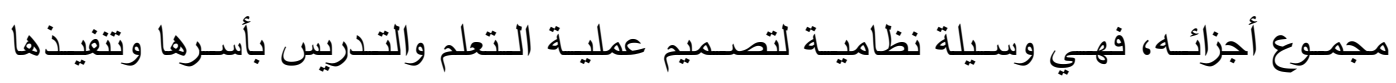

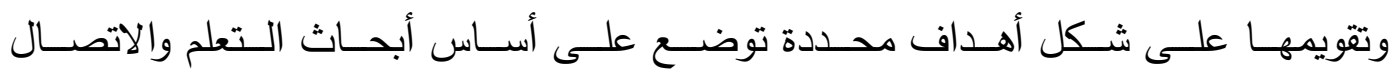




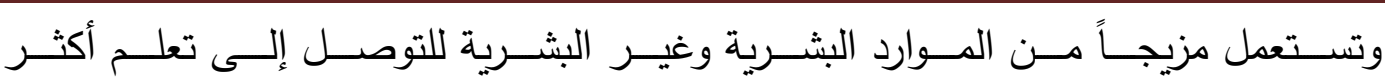

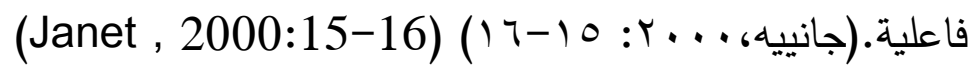

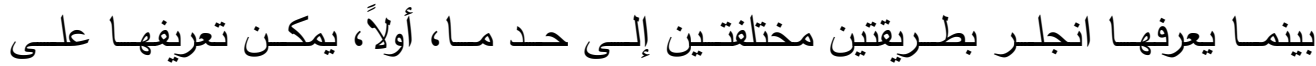

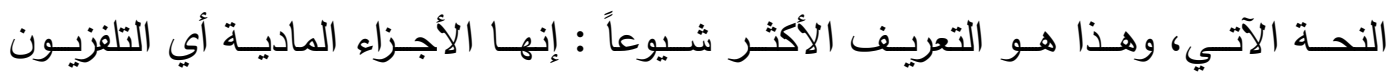

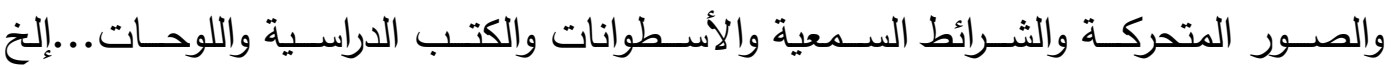
وهـي تثـكل أساسـاً أدوات وسـائط الاتصـال، ثانيـاً، والأكثر أهميـة، يمكن تعريفهـا أنهـا

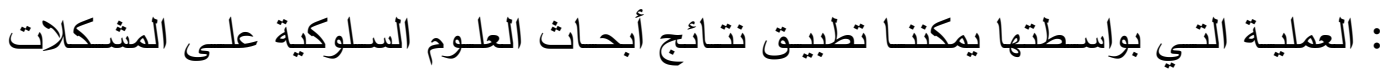

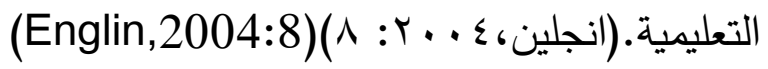

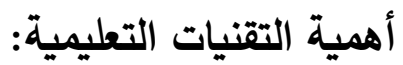
1- تشبع الكثير من حاجات المتعلمين وتثير اهتمامهم نحو موضوعات الدراسة.

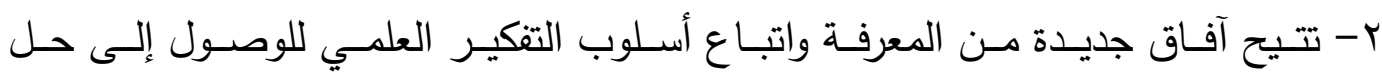
المشكلات ورفع مستوى أداء المتعلمين.

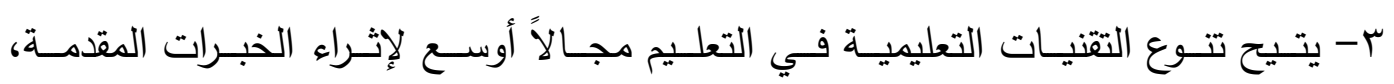
كما أنه يتحاشى الوقوع في اللفظية مما يؤدي إلى تعلم ذي اثر مستمر .

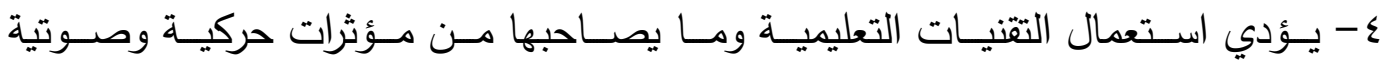

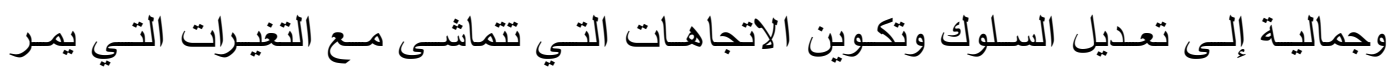

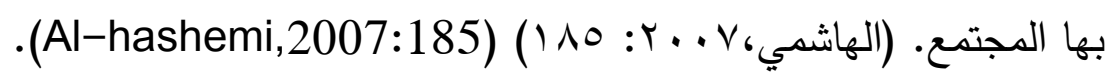
أهداف التقنيات التعليمية: 1- جعـل المتعلمـين يثـــون بقــراتهم علـى مواكبـة الصـعوبات والتصــدي للمشـكلات وتولد لديهم الحس بالاستقلال الذاتي.

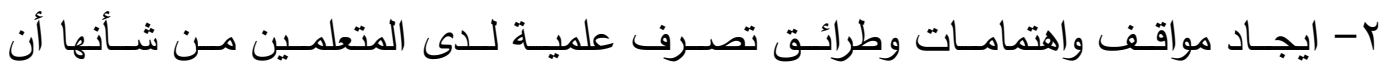
تساعد في تحسين نوعية الحياة.

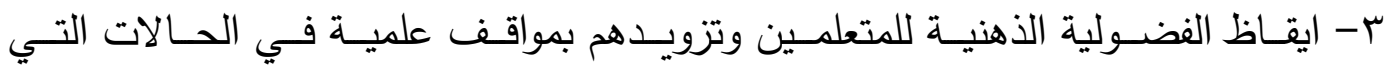
يتعذر تفسيرها ظاهرياً. ع - تمكين المتعلمين من اكتساب المعارف ومن إقامة برهنة منطقية.

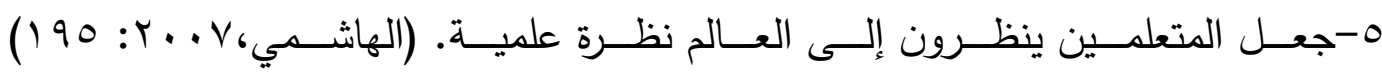
. (Al-hashemi,2007:195) التقنيات التعليمية والتقنيات التربوية:

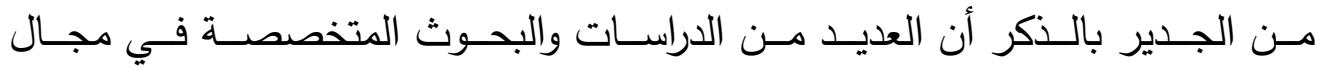

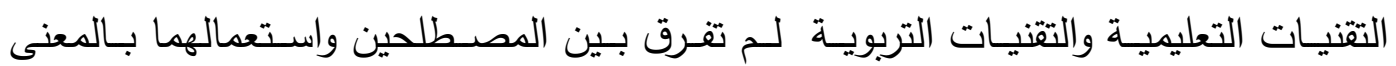


نفسـه إلا أنـه مـن الملاحظظهور اتجـاه متزايـــ للتمييز بينهمـا، بحيث يطلق مصـلح التقنيـات التعليميـة على العمليـات التي تتعلق بتصـيم عمليـة التعليم والتعلم، وتنفيذها

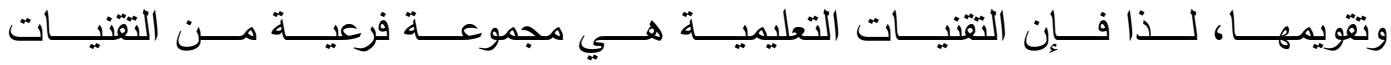

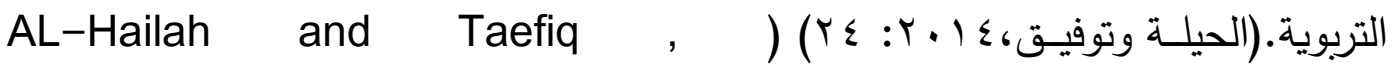
(2014:24 حدود البحث (Research limitation): ا ــ الحـدود المكانيـة : المــارس الحكوميـة والأهليـة النهاريـة التابعـة إلـى المديريـة العامــة للتربية في مركز محافظة كربلاء المقدسة. r- الحدود البشرية : إدارات المدارس.

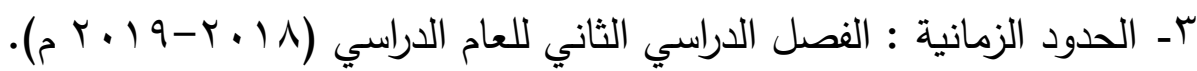
إجراءات البحث (Research Procedures): أولاً: منهج البحث (Research Methodology):

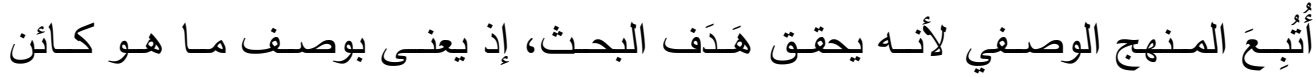

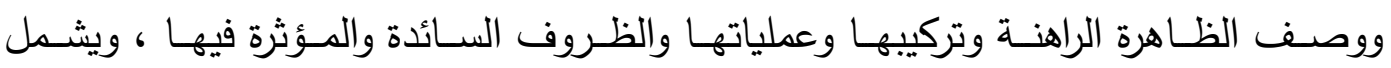

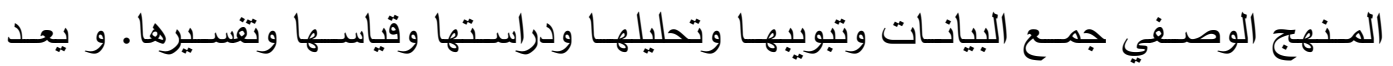

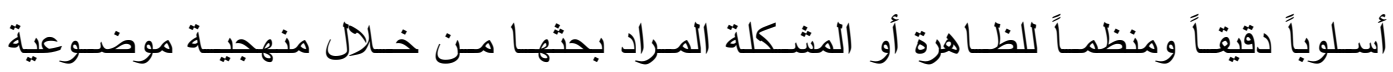

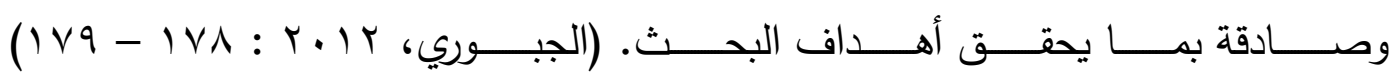
(Al-Jubouri,2012:178-179) ثانياً: مجتمع البحث (Research Population):

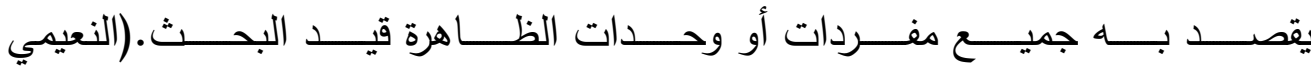

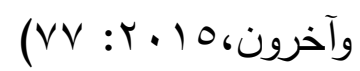

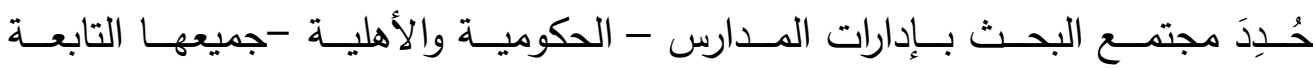

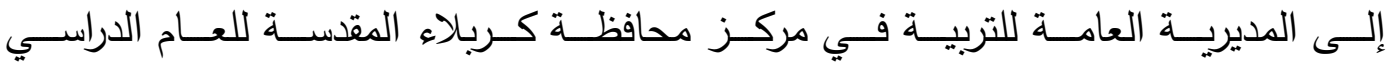

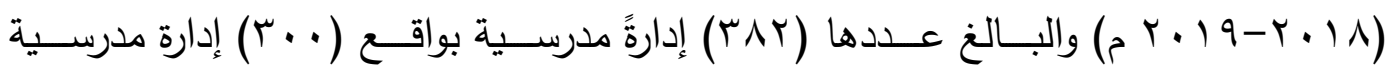

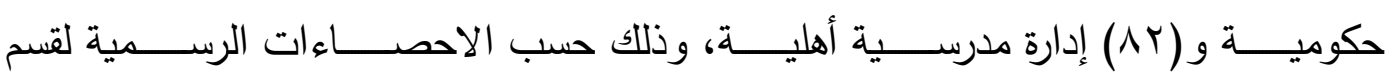

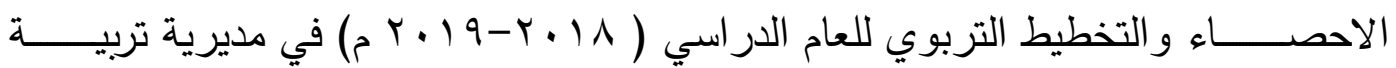
كربلاء المقدسة، الجدول (1) يوضح ذللك. 
جدول ( 1) يوضح توزيع مجتمع البحث في المدارس الدكومية والمدارس الأهلية

\begin{tabular}{|c|c|c|c|c|c|c|c|}
\hline \multicolumn{4}{|c|}{ إدارات المدارس الأهلية } & \multicolumn{4}{|c|}{ إدارات المدارس الحكومية } \\
\hline المئوية & 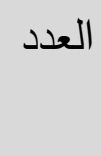 & الجنس الجن & المرحلة & المئوية & 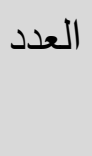 & 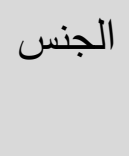 & المرحلة \\
\hline$\cdot, r$. & ro & ذكور & \multirow[t]{2}{*}{ الابتدائية } & 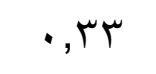 & 99 & 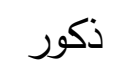 & \multirow[t]{2}{*}{ الابتدائية } \\
\hline • & rq & اناث & & $\cdot, r \cdot$ & 91 & ان اث & \\
\hline \multirow{2}{*}{\multicolumn{3}{|c|}{ ل ل ل ل يوجد }} & \multirow[t]{2}{*}{ المتوسطة } & $\cdot, 1 r$ & ro & ذ & \multirow[t]{2}{*}{ المتوسطة } \\
\hline & & & & $\cdot, \cdot V$ & $r \cdot$ & 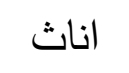 & \\
\hline$\cdot, r \cdot$ & 17 & ذكور & \multirow[t]{2}{*}{ الثانوية } & $\cdot, \cdot 1$ & $\varepsilon$ & ذكور & \multirow[t]{2}{*}{ الثانوية } \\
\hline$\cdot, 10$ & ir & اناث & & $\cdot, .0$ & 17 & اناث اناث & \\
\hline \multirow{2}{*}{\multicolumn{3}{|c|}{ لا يوجد }} & \multirow[t]{2}{*}{ الاعدادية } & $\cdot, .7$ & 19 & ذكور & \multirow[t]{2}{*}{ الاعدادية } \\
\hline & & & & $\cdot, .0$ & 17 & 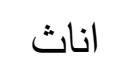 & \\
\hline$\% 1 \ldots=$ & \multicolumn{2}{|c|}{$\Delta r=$} & مج ك 5 & $\% 1 \ldots=$ & \multicolumn{2}{|c|}{$r \ldots=$} & مج ك \\
\hline
\end{tabular}

ثالثاً: عينة البحث (Research Sample): تعرج

تعـرف العينـة بصـورة عامـة أنهـا مجموعـة جزئيـة مـن المجتمـع الاحصـائي يجـري

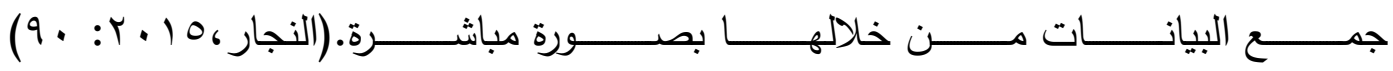
(Al-Najjar,2015:90) وتعـرف العينـة الطبقيـة بأنهـا العينـة التـي يجـري فيهـا تقسيح

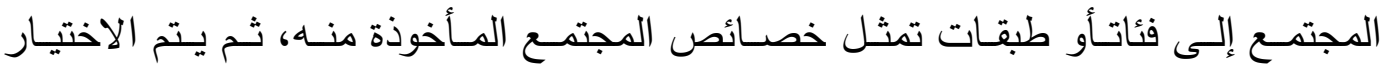

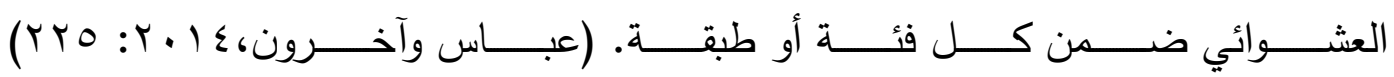

(Abbas and others, 2014:225)

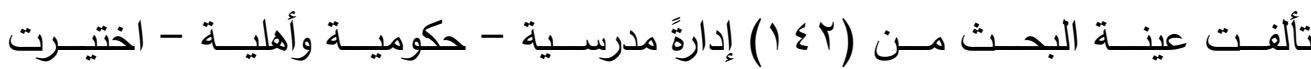

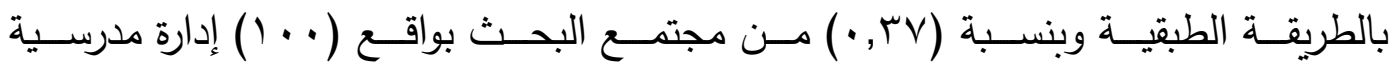

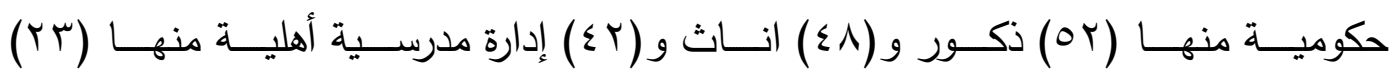
ذكور و(1) إ) اناث، والجدول (r) يوضح ذلك:

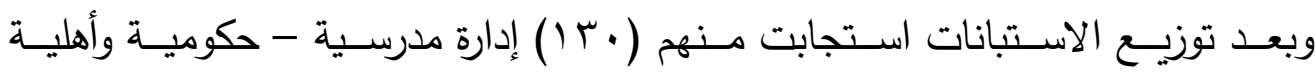

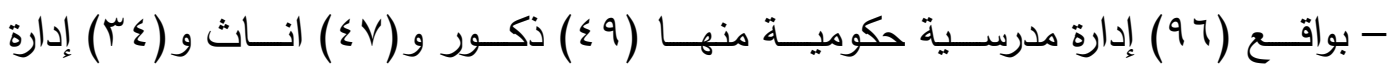
مدرسية أهلية منها (·• (Y) ذكور و (ع () اناث. 
جدول (r) يوضح توزيع عينة البحث حسب المرحلة الدراسية والجنس

\begin{tabular}{|c|c|c|c|c|c|}
\hline \multicolumn{3}{|c|}{ إدارات المدارس الحكومية } & \multicolumn{3}{|c|}{ إدارات المدارس الحكومية } \\
\hline \multicolumn{2}{|c|}{ العدد العد } & المرحلة & \multicolumn{2}{|c|}{ العدد العد } & المرحلة \\
\hline \multicolumn{2}{|c|}{ tr } & الابتدائية & \multicolumn{2}{|c|}{ Tr } & الابتدائية \\
\hline \multicolumn{2}{|c|}{ ل ل ايوجد } & المتوسطة & \multicolumn{2}{|c|}{11} & المتوسطة \\
\hline \multicolumn{2}{|c|}{$1 \leqslant$} & الثانوية & \multicolumn{2}{|c|}{ v } & الثانوية \\
\hline \multicolumn{2}{|c|}{ لا يوجد } & الاعدادية & \multicolumn{2}{|c|}{ ir } & الاعدادية \\
\hline \multicolumn{2}{|c|}{$\leqslant 1=$} & مج ك & \multicolumn{2}{|c|}{$1 \ldots=$} & مج ك \\
\hline 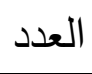 & الجنس الجس & المرحلة & 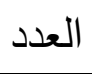 & الجنس الجس & المرحلة \\
\hline 10 & ذكور & \multirow[t]{2}{*}{ الابتدائية } & Tr & ذكور & \multirow[t]{2}{*}{ الابتدائية } \\
\hline ir & 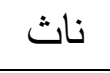 & & $r$. & 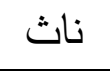 & \\
\hline \multirow{2}{*}{\multicolumn{2}{|c|}{ لا يوجد }} & \multirow[t]{2}{*}{ المتوسطة } & 11 & ذكور & \multirow[t]{2}{*}{ المتوسطة } \\
\hline & & & v & 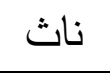 & \\
\hline$\wedge$ & ذكور & \multirow[t]{2}{*}{ الثانوية } & 1 & ذكور & \multirow[t]{2}{*}{ الثانوية } \\
\hline 7 & 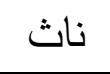 & & 7 & 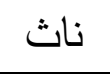 & \\
\hline \multirow{2}{*}{\multicolumn{2}{|c|}{ ل لا يوجد }} & \multirow[t]{2}{*}{ الاعدادية } & v & ذكور & \multirow[t]{2}{*}{ الاعدادية } \\
\hline & & & 0 & ناث & \\
\hline \multicolumn{2}{|c|}{$1=$} & مج ك & \multicolumn{2}{|c|}{$1 \ldots=$} & مج ك \\
\hline
\end{tabular}

رابعاً: أداة البحث (Research Tool):

مَرَ بناء أداة الاختبار على وفق الخطوات الآتية:

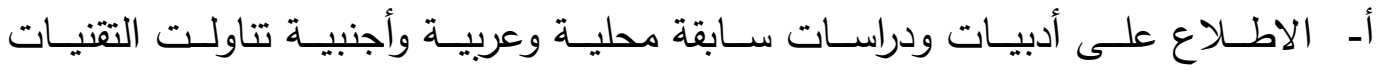

$$
\text { التعليمية الحديثة. }
$$

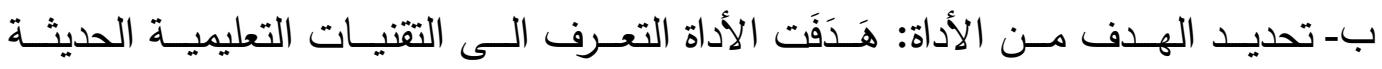
المتوافرة في المدارس الحكومية والأهلية في مركز محافظة كربلاء.

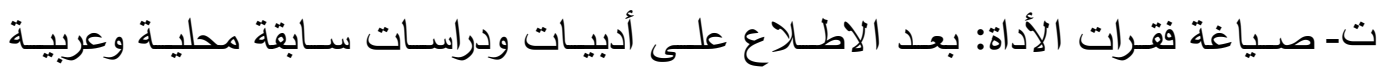

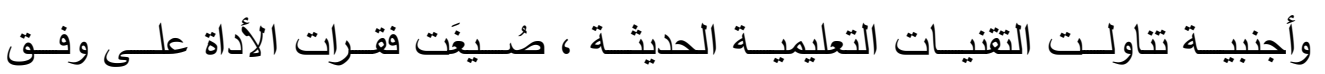

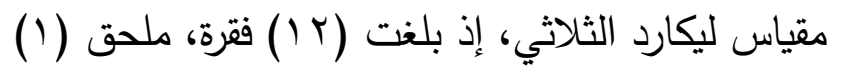
ث- صياغة تعليمات الأداة:

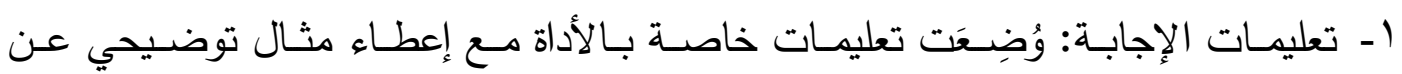


ץ- تعليمـات التصــحيح: لغـرض تصـحيح اسـتجابات أفـراد العينـة، تُعطىى درجـة واحـدة

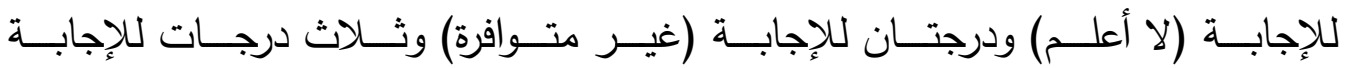

(متوافرة).

\section{ج- عدق الأداة (Tool Validity):}

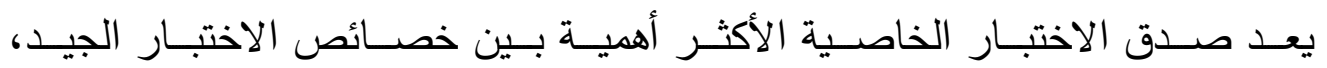

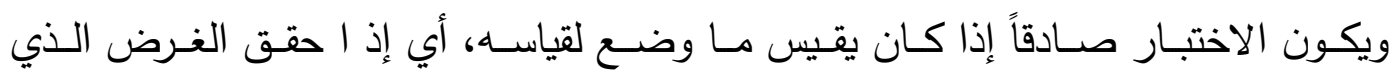

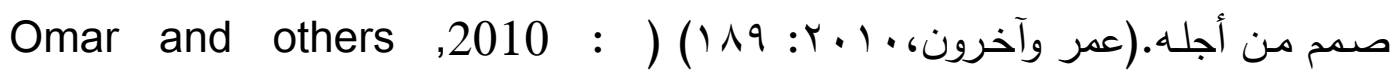
189) وللتحقق من صدق الاختبار اعتمد الباحثان نوعين من الصدق هما :

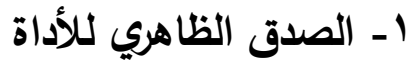

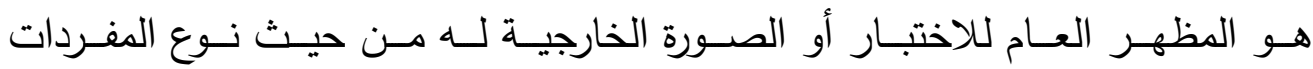

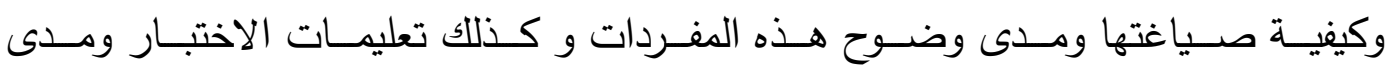

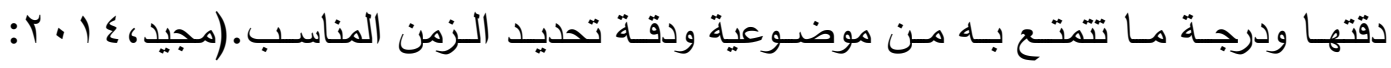

(Majeed, 2014:49)( $(9$

ويكـون التوصـل إليـهـ مـن خــلال حكـم الخبـراء والمختصـين علـى درجـة تمثيـل الاختبـار للسـمة المقاسـة، لـذلك عرضـت الاسـتبانة على مجموعـة مـن الخبـراء لإبــاء

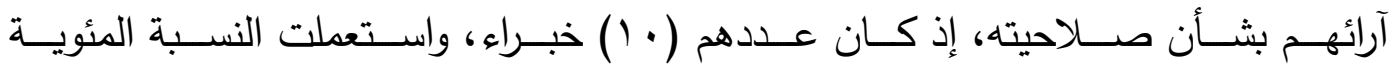

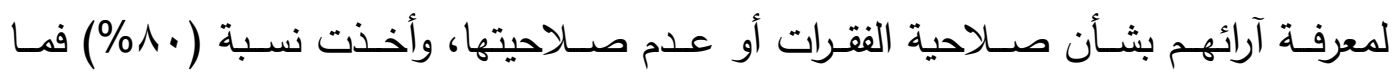

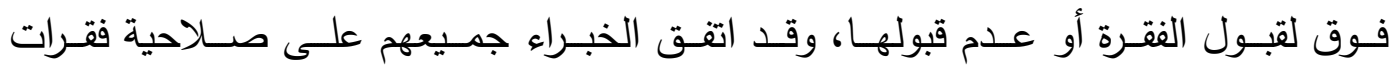

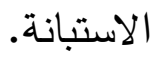

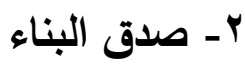

يهدف صـدق البنـاء إلى تحديد عدد الســات والصـفات التي يتميز بها الاختبـار

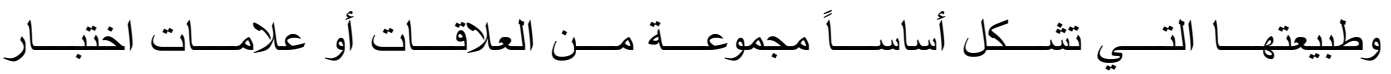

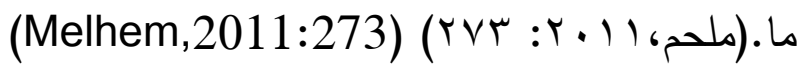

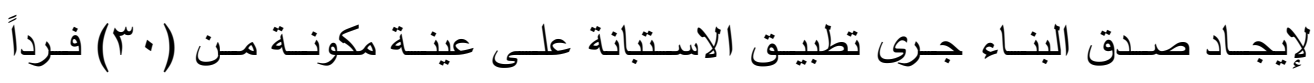

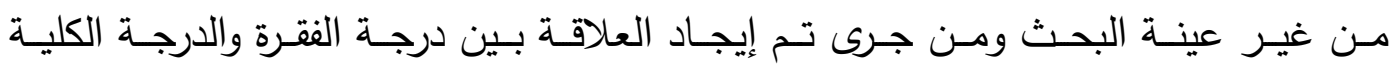

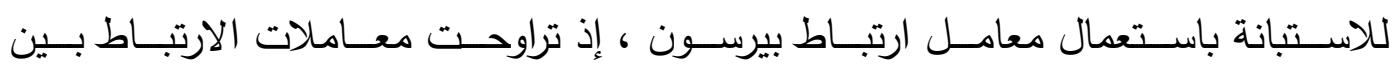

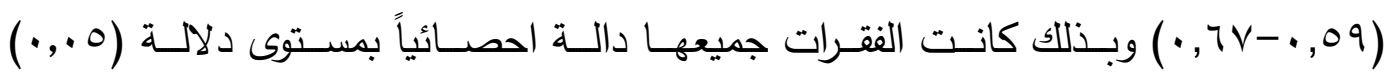

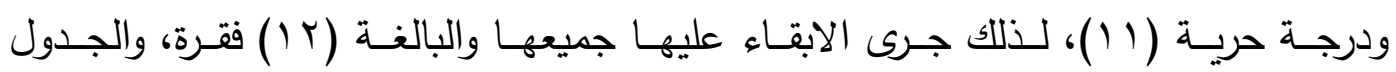

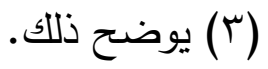


جدول (r) يوضح العلاقة بين درجة الفقرة والدرجة الكلية للاستبانة

\begin{tabular}{|c|c|c|}
\hline ت & الفقرة & معامل الارتباط \\
\hline 1 & سبورة ذكية & $\cdot, 7$ \\
\hline r & ل ل ابتوب & $\cdot$, TV \\
\hline$r$ & مسجل كاسيت & זT, \\
\hline$\varepsilon$ & داتا شو Data show & $\cdot, 09$ \\
\hline 0 & الثاشة الذكية & $\cdot, 7)$ \\
\hline 7 & آلة تصوير & • \\
\hline V & انترنيت & $\cdot, 01$ \\
\hline$\wedge$ & أشرطة سمعية & $\cdot, 7 \leqslant$ \\
\hline 9 & أشرطة فيديو & $\cdot, 09$ \\
\hline 1. & مجهر & $\cdot, 70$ \\
\hline 11 & هاتف ذكي & $\cdot, 7 \cdot$ \\
\hline ir & جهاز العارض فوق الرأس & 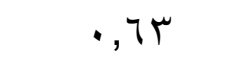 \\
\hline
\end{tabular}

ح- ثبات الأداة (Reliability Tool):

إن الثبات شرط ضروري أو لازم للصدق فإذا قلنا أن المقياس يقيس ما وضع

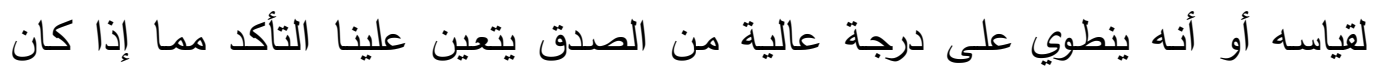

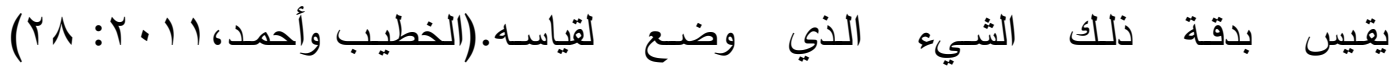
يقصد بالثبات مستوى الدقة التي يقيس (Al-khatib and Ahmad,2011:28)

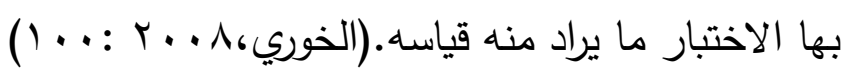

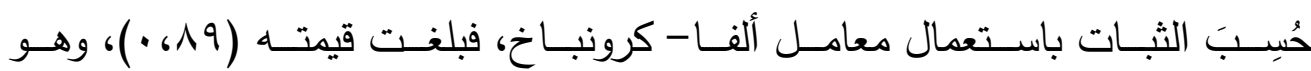

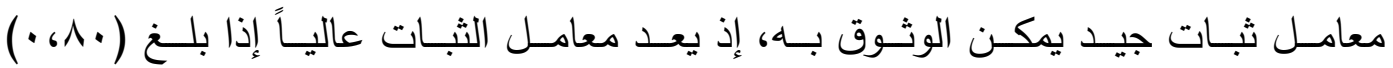

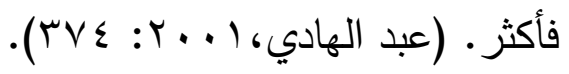
خامساً: الوسائل الإحصائية (Statistical means):

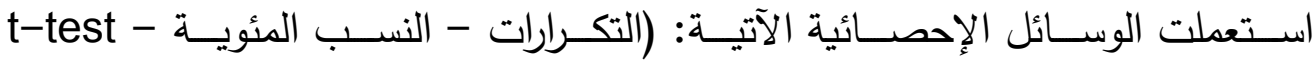

(Annovaسادساً: عرض النتائج (Results Presentation):

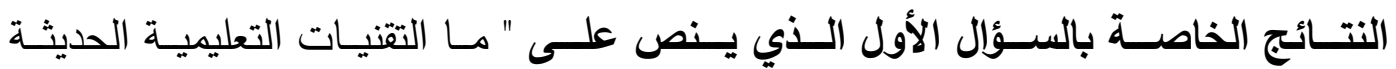

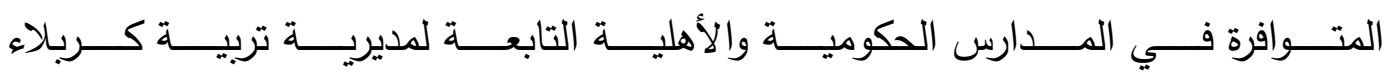

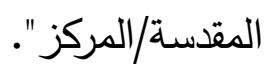


وللإجابـة عـن هـا السـؤال جـرى حسـاب التكـرارات والنسـبة المئويـة لكل فقـرة مـن

$$
\text { الفقرات، والجدولان (ع) (0) يوضحان ذللك. }
$$

جدول (؛ ) يوضح التكرارات والنسبة المئوية لاستجابة أفراد العينة للمدارس الحكومية

\begin{tabular}{|c|c|c|c|c|c|c|c|}
\hline ت & تقنيات التعليم & $\begin{array}{l}\text { لا أعلم } \\
\text { (التكرار ) }\end{array}$ & $\%$ & 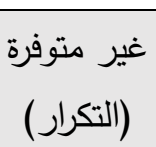 & $\%$ & (التكرار ) متوفرة & $\%$ \\
\hline 1 & سبورة ذكية & . & $\%$. & 97 & $\% 1 \ldots$ & . & $\%$ \\
\hline$r$ & ل الابتوب & 0 & $\% 0$ & vi & $\% \vee \varepsilon$ & $r$. & $\%$ \% \\
\hline$r$ & مسجل كاسيت & . & $\%$. & r & $\%) \leq$ & 人 & $\% \wedge 4$ \\
\hline$\varepsilon$ & داتا شو Data show & . & $\%$. & 97 & $\% 1 \ldots$ & . & $\%$ \\
\hline 0 & شاشة الذكية & . & $\%$. & 97 & $\% 1 \ldots$ & . & $\%$. \\
\hline 7 & آلة تصوير & 1 & $\% 1$ & 10 & $\% 17$ & $\wedge$. & $\% \wedge r$ \\
\hline$v$ & انترنيت & . & $\%$. & 74 & $\% 79$ & r. & $\%$ \% \\
\hline$\wedge$ & أشرطة سمعية & 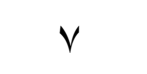 & $\% \vee$ & rr & $\%$ \%r & $T V$ & $\% \vee$. \\
\hline 9 & أشرطة فيديو & · & $\%$. & $\Lambda \varepsilon$ & $\% \wedge \wedge$ & ir & $\%$ \\
\hline 1. & مجهر & 1 & $\% 1$ & 17 & $\%$ ।V & vq & $\% \wedge r$ \\
\hline 11 & هاتف ذكي & . & $\%$. & 97 & $\% 1 \ldots$ & . & $\%$. \\
\hline ir & جهاز العارض فوق الرأس & . & $\%$. & 97 & $\% 1 \ldots$ & . & $\%$. \\
\hline
\end{tabular}

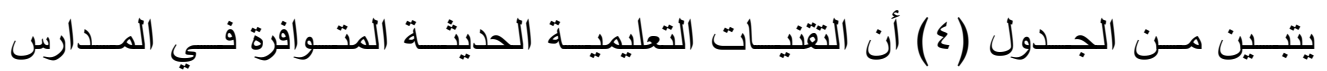

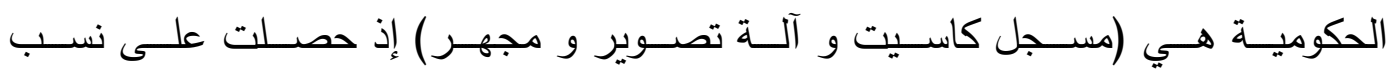

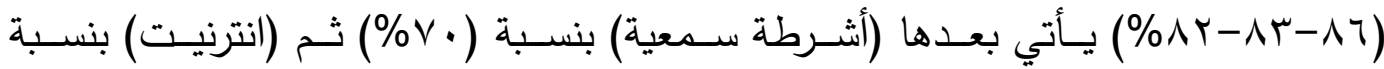

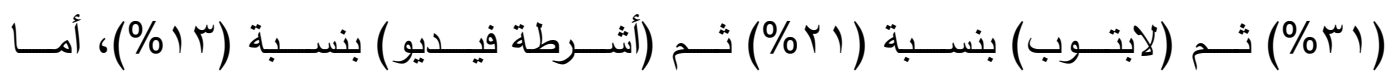
التقنيات البقية فقد حصلت على نسبة (• (\%).

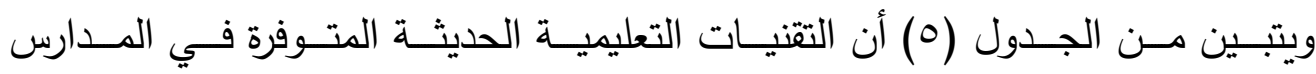

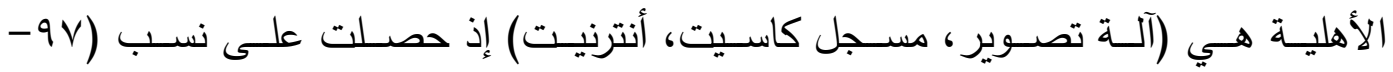

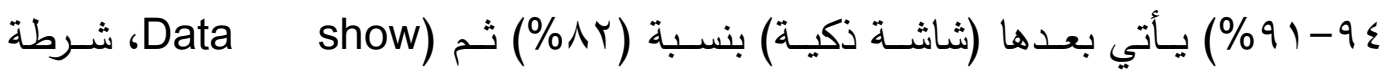

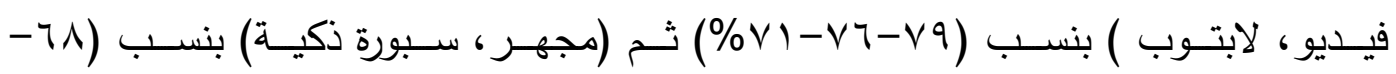

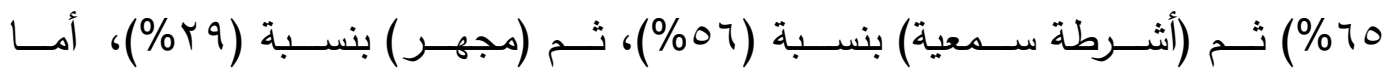
جهاز العارض فوق الرأس فقد حصل على نسبة (•\%). 
جدول (•) يوضح التكرارات وإلنسبة المئوية لاستجابة أفراد العينة للمدارس الأهلية

\begin{tabular}{|c|c|c|c|c|c|c|c|}
\hline$ت$ & تقنيات التعليم & (التكرار ) & $\%$ & 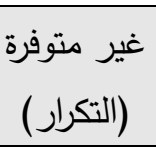 & $\%$ & (التكرار) & $\%$ \\
\hline 1 & سبورة ذكية & . & $\%$. & ir & $\%$ ro & rt & $\% 70$ \\
\hline r & ل لابتوب & . & $\%$. & 1. & $\%$ \% & $r \varepsilon$ & $\% \vee 1$ \\
\hline$r$ & مسجل كاسيت & . & $\%$. & r & $\%\urcorner$ & rt & $\% 9 \leq$ \\
\hline$\varepsilon$ & داتا شو Data show & . & $\%$. & v & $\% r_{1}$ & rV & $\% \vee q$ \\
\hline 0 & شاشة الذكية & 1 & $\% 1$ & 0 & $\% 10$ & rA & $\% \wedge r$ \\
\hline 7 & آلة تصوير & . & $\%$ & 1 & $\% 1$ & Tr & $\% 9 \vee$ \\
\hline v & انترنيت & . & $\%$. & r & $\% 9$ & r & $\% 91$ \\
\hline$\wedge$ & أشرطة سمعية & r & $\% 9$ & ir & $\%$ ro & 19 & $\% 07$ \\
\hline 9 & أشرطة فيديو & . & $\%$. & $\wedge$ & $\% r \varepsilon$ & rt & $\% \vee 4$ \\
\hline 1. & مجهر & . & $\%$ & 11 & $\%$ \%r & r & $\% \uparrow$ \\
\hline 11 & هاتف ذكي & . & $\%$. & $r \varepsilon$ & $\% \times 1$ & 1. & $\%$ \% \\
\hline ir & جهاز العارض فوق الرأس & . & $\%$. & $r \varepsilon$ & $\% 1 \ldots$ & . & $\%$ \\
\hline
\end{tabular}

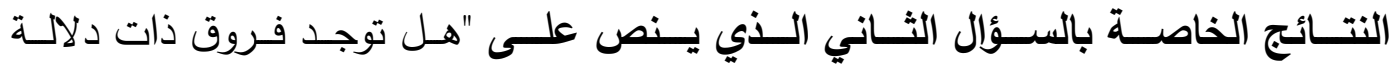

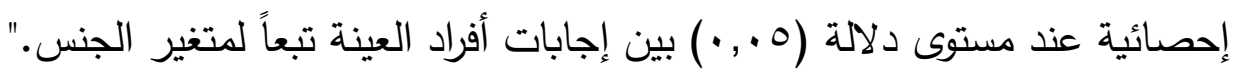

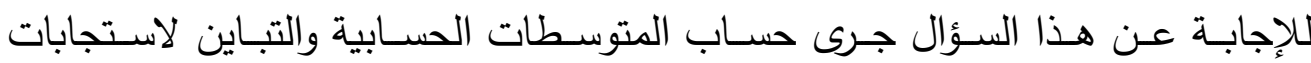

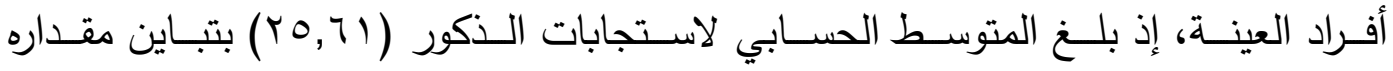

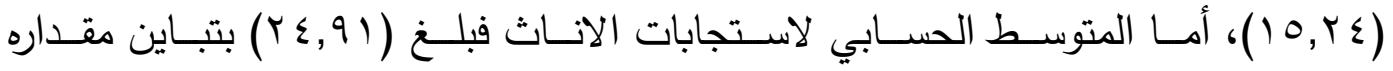

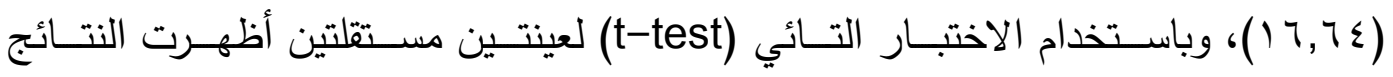

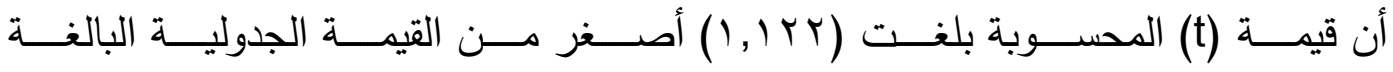

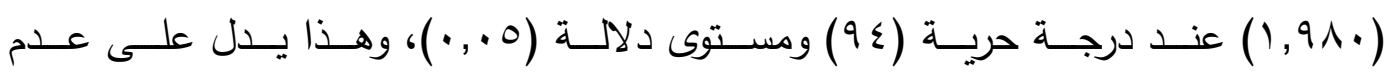
وجـود فـروق ذات دلالــة إحصــائية بـين متوسـطـي اسـتجابات افـراد العينـة، والجـدولان

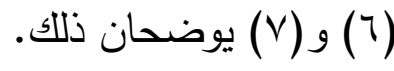

جدول (†) يوضح (t-test) لالالة الفروق بين متوسط إجابات أفراد العينة تبعاً لمتغير الجنس في المدارس الحكومية

\begin{tabular}{|c|c|c|c|c|c|c|c|}
\hline \multirow[t]{2}{*}{ الدجمو عة } & \multirow[t]{2}{*}{ العدد } & \multirow{2}{*}{ الحسابي } & \multirow[t]{2}{*}{ التباين } & \multirow{2}{*}{ الحرية } & \multicolumn{2}{|c|}{ قيمة t } & \multirow[t]{2}{*}{ الدلالة } \\
\hline & & & & & الجدولية & المحسوبة & \\
\hline ذكور & $\leqslant 9$ & $(Y 0,7)$ & $10, Y \leqslant$ & $9 \varepsilon$ & $1,9 \wedge$. & $1,1 K Y$ & \\
\hline اناث & $\varepsilon V$ & $r \leqslant, q 1$ & $17,7 \leqslant$ & & & & \\
\hline
\end{tabular}


جدول (V) يوضح (t-test) لدالة الفروق بين متوسط إجابات أفراد العينة تبعاً لمتغير

الجنس في المدارس الأهلية

\begin{tabular}{|c|c|c|c|c|c|c|c|}
\hline \multirow[t]{2}{*}{ المجمو عة } & \multirow[t]{2}{*}{ العدد } & \multirow{2}{*}{ الحستوسي } & \multirow[t]{2}{*}{ التباين } & \multirow{2}{*}{ الحرجية } & \multicolumn{2}{|c|}{ قبمة t } & \multirow[t]{2}{*}{ الدلالة } \\
\hline & & & & & الجدولية & الدحسوبة & \\
\hline ذكور & T. & $r 1,1 r$ & $I T, r$. & Tr & $Y, \cdot \Sigma Y$ &., 701 & غير | ت بير \\
\hline اناث & $1 \varepsilon$ & $r_{\cdot}, r_{0}$ & $10, \pi 4$ & & & & \\
\hline
\end{tabular}

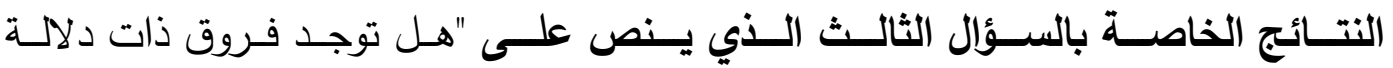

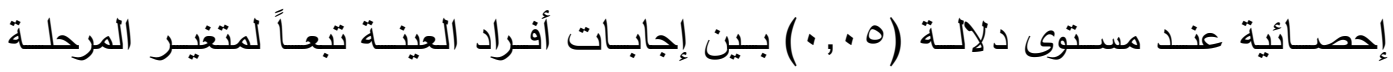

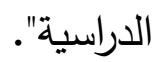

للإجابــة عـن هـذا السـؤال فيهـا يخص المــارس الحكوميـة جـرى حســاب المتوســـ

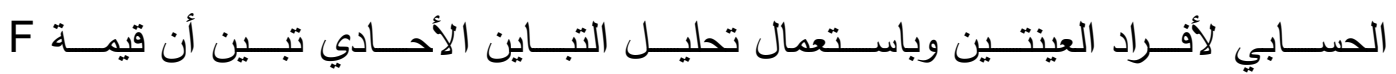

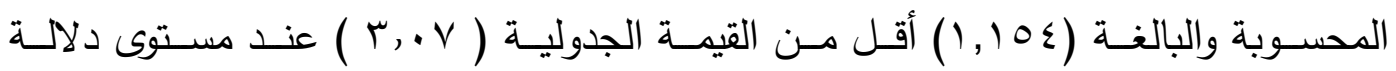

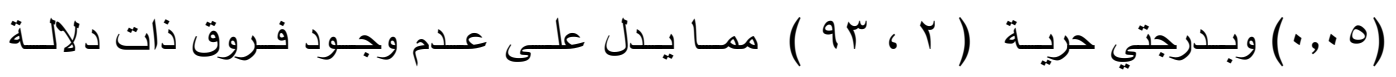

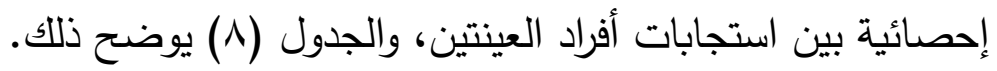

\section{جاول (^) (^)}

يوضح تحليل التباين الأحادي (ANOVA) لاستجابات افراد العينتين

\begin{tabular}{|c|c|c|c|c|c|}
\hline مصدر & مجموع & درجة & متوسط مجموع & \multicolumn{2}{|c|}{ القيمة الفائية } \\
\hline التباين & المربعات & الحرية & المربعات & الجدولية & المحسوبة \\
\hline المجمو عات & $r \leqslant r, r)$ & $\Gamma$ & $|v|, 1.0$ & \multirow{3}{*}{$1,10 \leqslant$} & \multirow{3}{*}{$r, \cdot V$} \\
\hline المجمو عات & IrVAO,OYq & $9 r$ & $|\leq \Lambda, Y \mu|$ & & \\
\hline الكجموع & $I \varepsilon \mid r V, V \varepsilon$ & 90 & & & \\
\hline
\end{tabular}

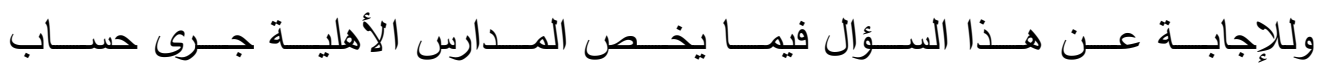

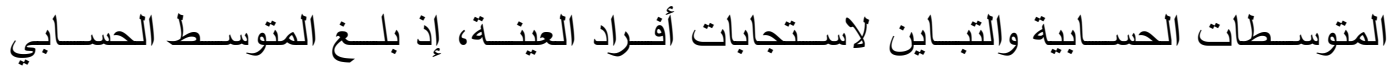

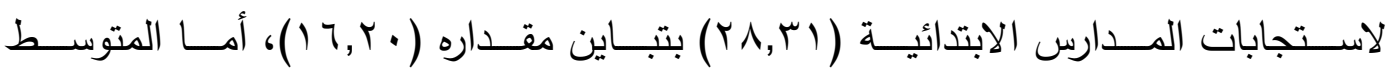

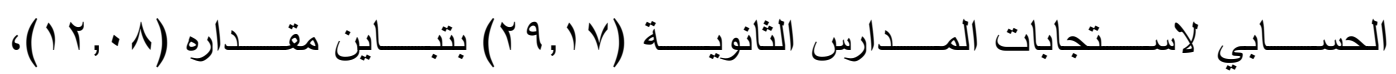

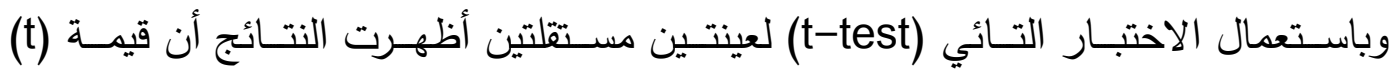

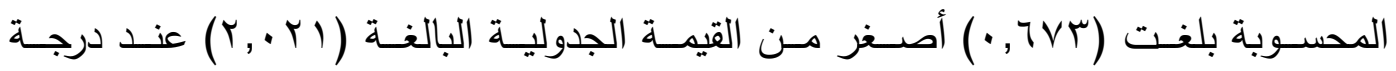

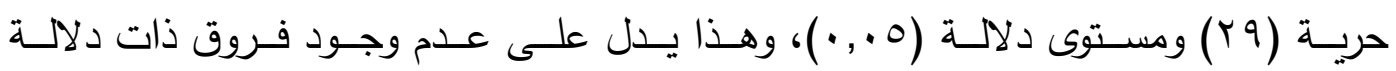

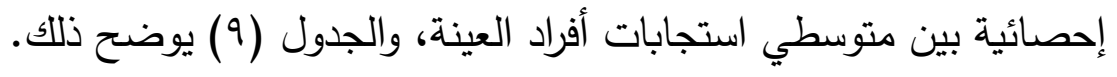


جدول (9) يوضح (t-test) لدلالة الفروق بين متوسط إجابات أفراد العينة تبعاً لمتغير

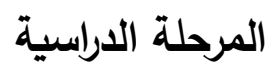

\begin{tabular}{|c|c|c|c|c|c|c|c|}
\hline \multirow[t]{2}{*}{ المجمو عة } & \multirow[t]{2}{*}{ العدد } & \multirow{2}{*}{ الحسابي } & \multirow[t]{2}{*}{ التباين } & \multirow{2}{*}{ الحرجة } & \multicolumn{2}{|c|}{ قيمة t } & \multirow[t]{2}{*}{ الدلالة } \\
\hline & & & & & الجدولية & المحسوبة & \\
\hline ابتدائية & $Y V$ & $\vec{r} \wedge, r)$ & $17, Y$. & \multirow[t]{2}{*}{$r q$} & \multirow[t]{2}{*}{$Y_{,} \cdot Y_{1}$} & \multirow[t]{2}{*}{$\cdot, T V T$} & \\
\hline ثانوية & $1 \leq$ & $r q, 1 v$ & $\mid r, \cdot \Lambda$ & & & & \\
\hline
\end{tabular}

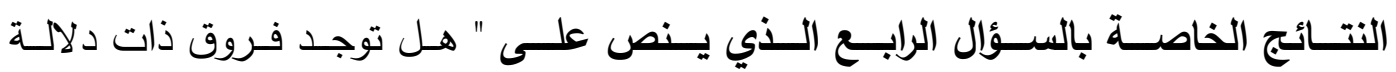

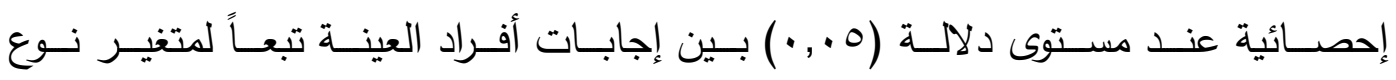

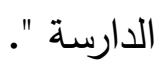

للإجابـة عـن هذا السؤال جـرى حسـاب المتوسـات الحسـابية والتبـاين لاسـتجابات

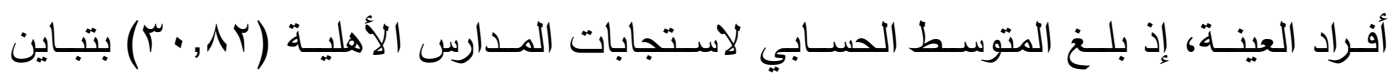

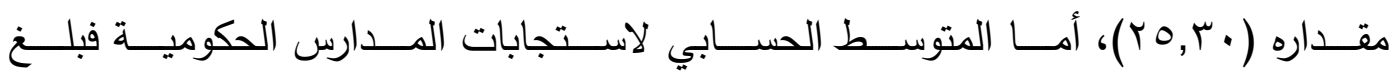

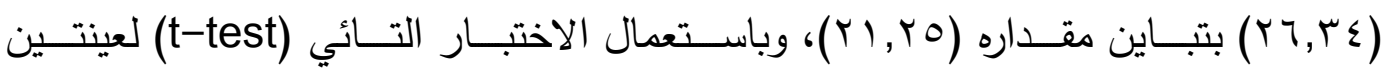

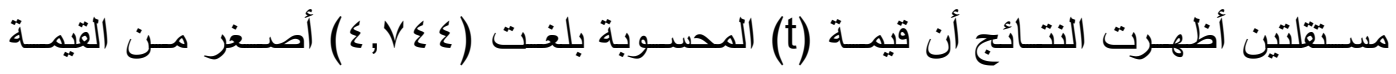

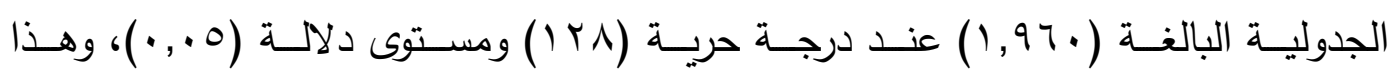

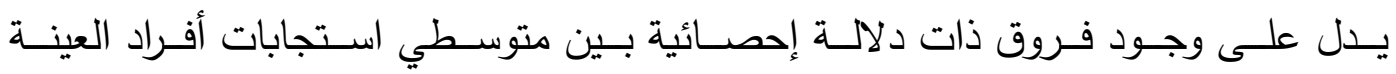

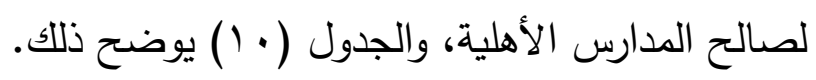
جدول (1.)

يوضح (t-test) لدالة الفروق بين متوسط إجابات أفراد العينة تبعاً لمتفير نوع الدراسة

\begin{tabular}{|c|c|c|c|c|c|c|c|}
\hline \multirow[t]{2}{*}{ المجمو عة } & \multirow[t]{2}{*}{ العدد } & \multirow{2}{*}{ الحستوسي } & \multirow[t]{2}{*}{ التباين } & \multirow{2}{*}{ درجية } & \multicolumn{2}{|c|}{ قيمة t } & \multirow[t]{2}{*}{ الدلالة } \\
\hline & & & & & الجدولية & المحسوبة & \\
\hline أهلية & $r \varepsilon$ & $r \cdot, \wedge r$ & $\mu_{0, T}$. & $I Y A$ & $1,97$. & $\varepsilon, V \leqslant \varepsilon$ & دالة \\
\hline حكومية & 97 & $r \tau, r \varepsilon$ & TI, YO & & & & \\
\hline
\end{tabular}

سابعاً: الاستنتاجات (Conclusions):

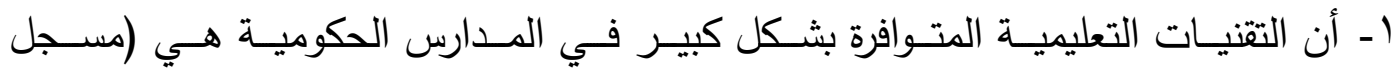

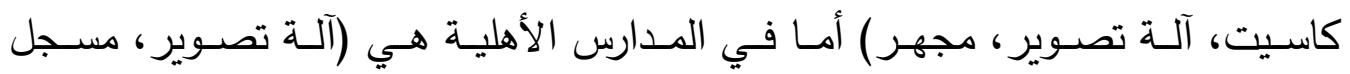
كاسيت، أنترنيت، شاشة ذكية)

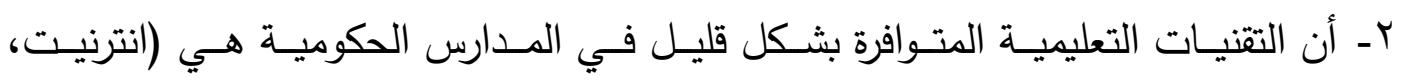

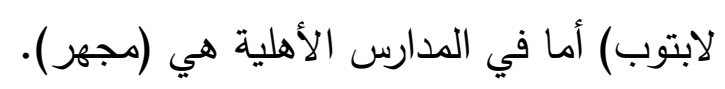

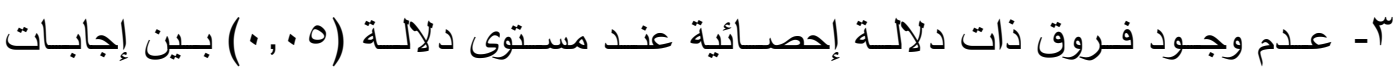
أفراد العينة تبعاً لمتغير الجنس. 
ع ــ عـدم وجـود فـروق ذات دلالــة إحصـائية عنـــ مسـتوى دلالـة (0 . . ) بـين إجابـات أفراد العينة تبعاً لمتغير المرحلة الدراسية. هـ وجـود فـروق ذات دلالــة إحصـائية عنـد مسـتوى دلالــة (0 . . •) بــين إجابـات أفـراد العينة تبعاً لمتغير نوع الدراسة ولصالح المدارس الأهلية.

ثامناً: التوصيات (Recommendations): في ضــوء النتـائج التي توصـل إليهـا البحـث نوصـي السـادة أصــاب القـرار في المجال التربوي بالآتي:

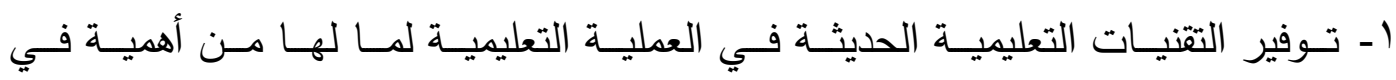
عمليتي التعلم والتعليم.

r- توفير الغرف الصفية الملائمة لاستعمال التقنيات التعليمية الحديثة. بـ إدخـال الملاكـات التدريسـية دورات تدربيــة لـتعلم كيفيـة اسـتعمال التقنيـات التعليميـة الحديثة.

تاسعاً: المقترحات (Suggestions): استكمالاً لهذا البحث نقترح إجراء البحوث الآتية:

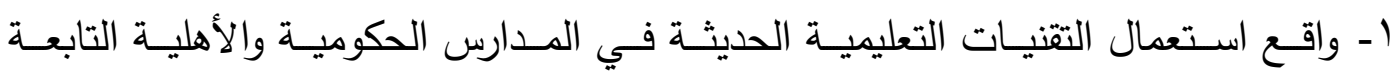
إلى المديرية العامة لتربية محافظة كربلاء المقدسة.

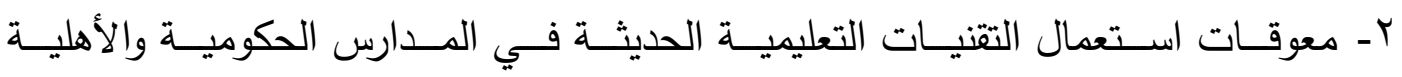
التابعة إلى المديرية العامة لتربية محافظة كربلاء المقدسة.

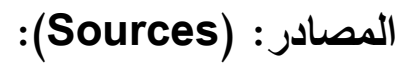

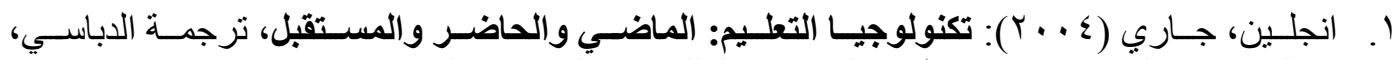

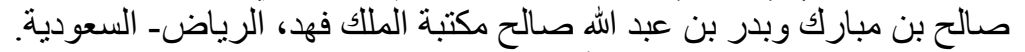

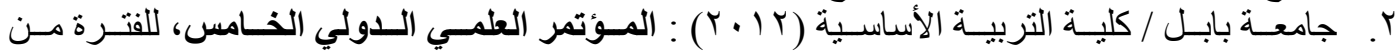

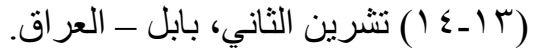

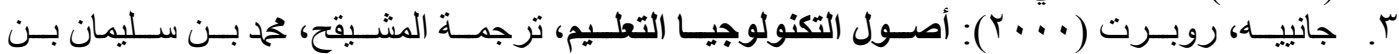

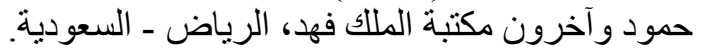

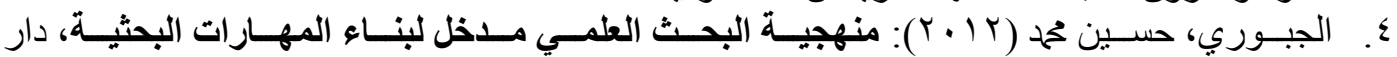

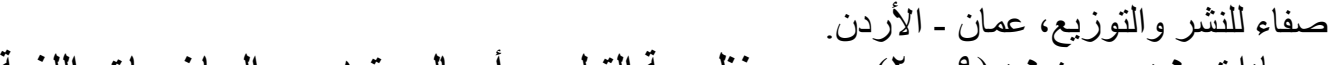

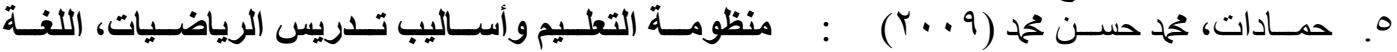

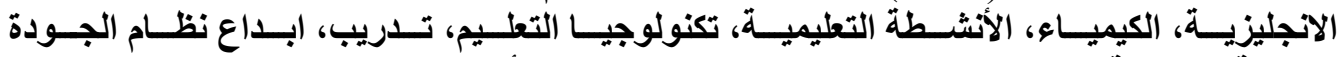

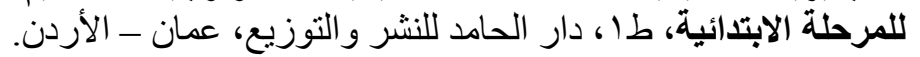

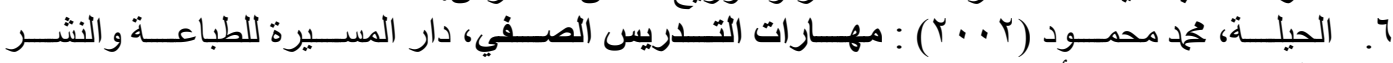
و التوزيع، عمان - الأردن.

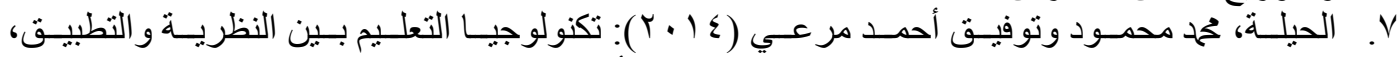

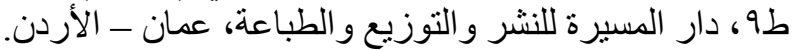

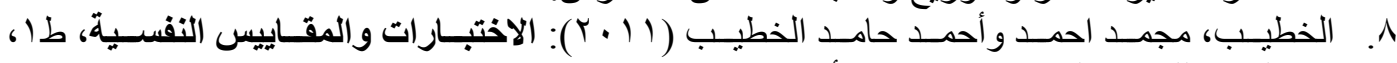
دار الحامد للنشر و التوزيع، عمان - الأردن.

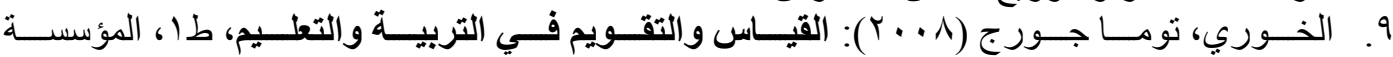
الجامعية للدر اسات و النشر و التوزيع، بيروت ــ لـ لبنان. 


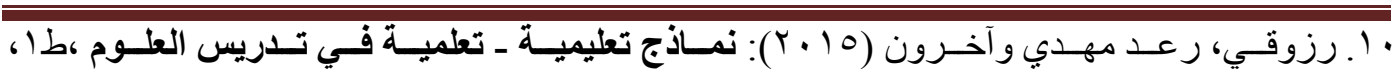

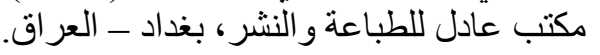

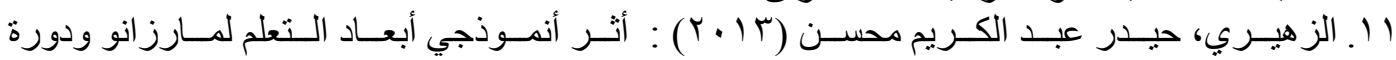

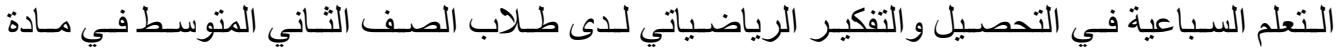

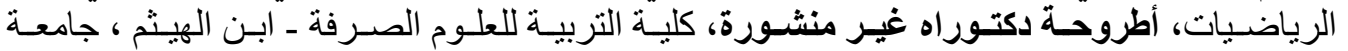

بغداد.

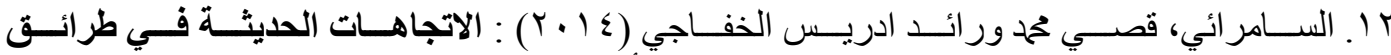
التدريس ، ط أ، دار دجلة للنشر و التوزيع، عمان ــ الأردن.

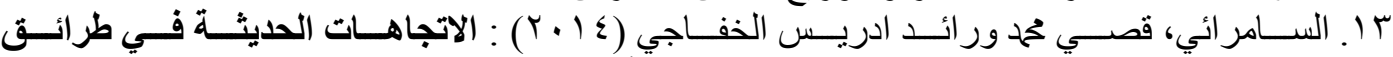

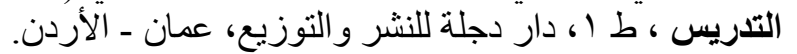

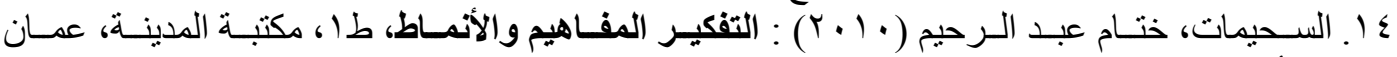

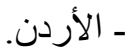

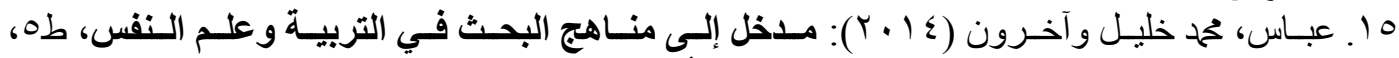

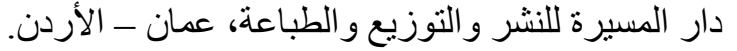

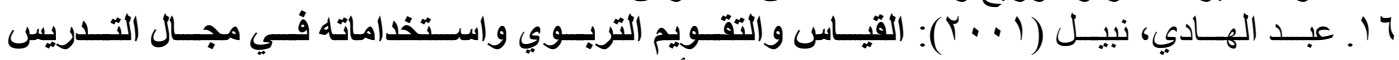

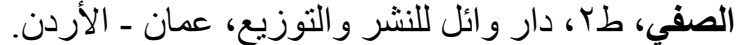

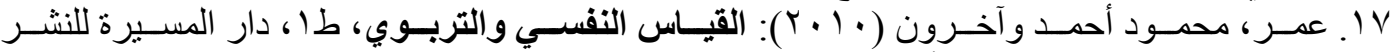
و التوزيع و الطباعة، عمان ـ الأردن.

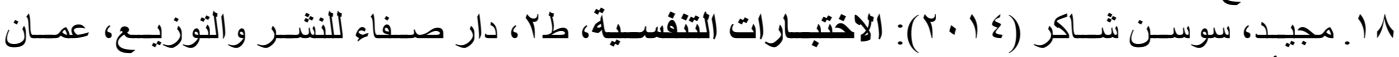

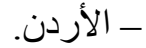

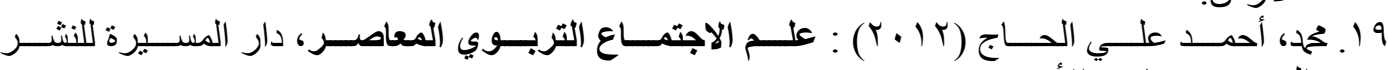

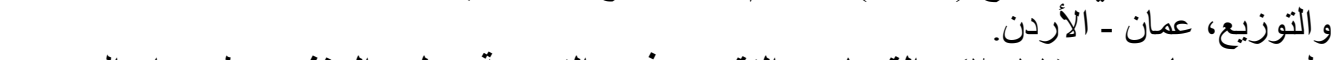

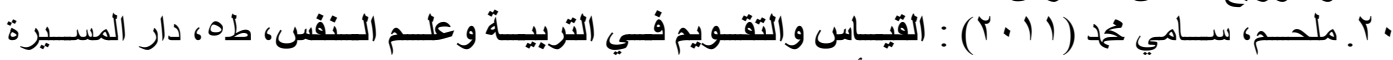
للطباعة و النشر و التوزيع، عمان ـ الأردن.

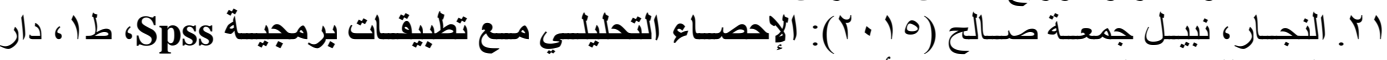

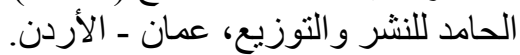

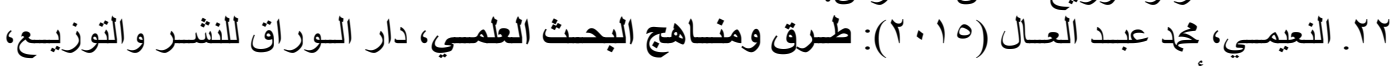

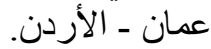

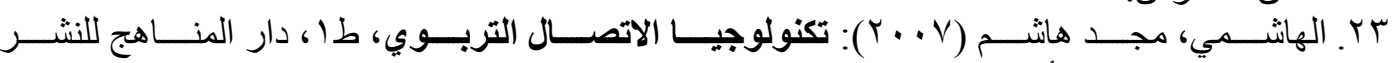

\section{Sources}

Abbas, Muhammad Khalil and others (2014): An Introduction to Research Methods in Education and Psychology, 5th floor, Al Masirah House for Publishing, Distribution and Printing, Amman - Jordan.

Abdel-Hadi, Nabil (2001): educational measurement and evaluation and its uses in the field of classroom teaching, 2nd edition, Wael House for Publishing and Distribution, Amman - Jordan.

Al-Hailah, Muhammad Mahmoud (2002): Classroom Teaching Skills, AlMasirah House for Printing, Publishing and Distribution, Amman Jordan.

Al-Hailah, Muhammad Mahmoud and Tawfiq Ahmad Merhi (2014): Educational Technology between Theory and Practice, 9th Edition, AlMasirah House for Publishing, Distribution and Printing, Amman Jordan.

Al-Hashemi, Majd Hashem (2007): Educational Communication Technology, 1st Floor, Dar Al-Manhajj Publishing and Distribution, Amman - Jordan

Al-Jubouri, Hussein Muhammad (2012): Scientific Research Methodology: An Introduction to Building Research Skills, Safaa House for Publishing and Distribution, Amman - Jordan. 
Al-Khatib, Muhammed Ahmad and Ahmad Hamed Al-Khatib (2011): Psychological tests and measures, 1st edition, Dar Al-Hamid for Publishing and Distribution, Amman - Jordan.

Al-Najjar, Nabil Jumaa Saleh (2015): Analytical Statistics with Spss Software Applications, 1st Floor, Dar Al-Hamid for Publishing and Distribution, Amman - Jordan.

Al-Nuaimi, Mohamed Abdel-Al (2015): Scientific Research Methods and Approaches, Dar Al-Warraq for Publishing and Distribution, Amman Jordan.

Al-Samarrai, Qusai Muhammad, and Raed Idris Al-Khafaji (2014): Modern Trends in Teaching Methods, 1st Floor, Dar Degla Publishing and Distribution, Amman - Jordan.

Al-Suhaimat, conclusion of Abdul Rahim (2010): thinking, concepts and patterns, 1st edition, Madinah Library, Amman - Jordan.

Al-Zuhairi, Haider Abdul-Karim Mohsen (2013): a model effect of the learning dimensions of Marzano and the seven-year learning course on achievement and mathematical thinking among middle school students in mathematics, unpublished doctoral thesis, College of Education for Pure Sciences - Ibn Al-Haytham, University of Baghdad.

Babylon University / College of Basic Education (2012): The Fifth International Scientific Conference, for the period from (13-14) November, Babil - Iraq.

El-Khoury, Toma George (2008): Measurement and Evaluation in Education, 1st edition, University Foundation for Studies, Publishing and Distribution, Beirut - Lebanon

Englin, Jari (2004): Educational Technology: Past, Present, and Future, translated by Al-Dabbasi, Saleh bin Mubarak and Bader bin Abdullah Saleh, King Fahd Library, Riyadh, Saudi Arabia.

Hammadat, Muhammad Hassan Muhammad (2009): (The education system and methods of teaching mathematics, English language, chemistry, educational activities, educational technology, training, creativity of the quality system for the primary stage, 1st floor, Dar AlHamid for Publishing and Distribution, Amman - Jordan.

Janet, Robert (2000): The Origins of Technology, Education, Translation of Al-Mushaigeh, Muhammad Bin Sulaiman Bin Hammoud et al. King Fahd Library, Riyadh - Saudi Arabia

Majeed, Sawsan Shaker (2014): Respiratory Tests, 2nd edition, Safaa House for Publishing and Distribution, Amman - Jordan.

Melhem, Sami Muhammad (2011): Measurement and Evaluation in Education and Psychology, 5th edition, Dar Al Masirah for Printing, Publishing and Distribution, Amman - Jordan.

Muhammad, Ahmad Ali Al-Hajj (2012): Contemporary Educational Sociology, Al-Masirah House for Publishing and Distribution, Amman Jordan.

Omar, Mahmoud Ahmed and others (2010): Psychological and Educational Measurement, 1st edition, Al Masirah House for Publishing, Distribution and Printing, Amman - Jordan.

Razzouki, Raad Mahdi and others (2015): Educational - learning models in teaching science, 1st floor, Adel Office for Printing and Publishing, Baghdad - Iraq. 
Samurai, Qusai Muhammad and Raed Idris Al-Khafaji (2014): Modern Trends in Teaching Methods, 1st Floor, Dar Degla Publishing and Distribution, Amman - Jordan.

\section{ملحق (1)}

استبانة استطلاعية إلى مديري المدارس الحكومية والأهلية في مركز محافظة كربلاء المقدسة للتعرف الى التقنيات التعليمية الحديثة المتوافرة

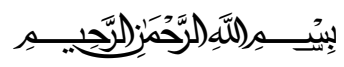

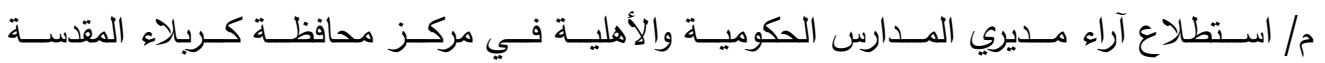
للتعرف الى التقنيات التعليمية الحديثة المتوافرة

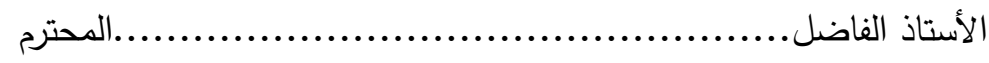

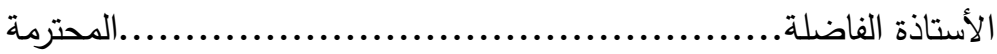
السلام عليكم ورحمة الله وبركاته

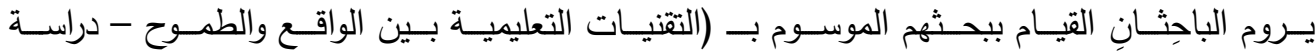

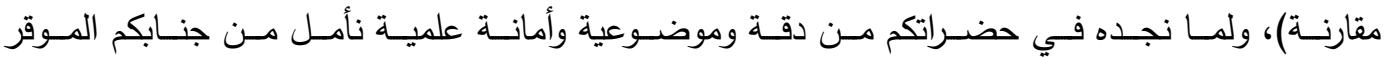

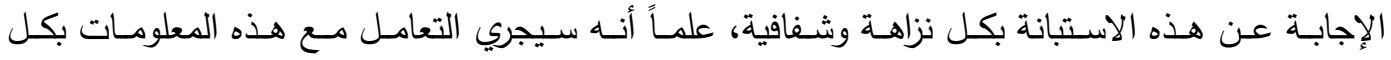
سرية، ولا داعي لذكر الاسم بوصفها تستعمل لأغراض البحث العلمي فقط. ولكم منا جزيل الثكر والامتتان

$$
\begin{aligned}
& \text { الباحثان } \\
& \text { م.م عمر فلاح عواد } \\
& \text { أمير مححد علي رسول عملح عراد }
\end{aligned}
$$
*رجى من جنابكم الموقر ملئ المعلومات أدناه.
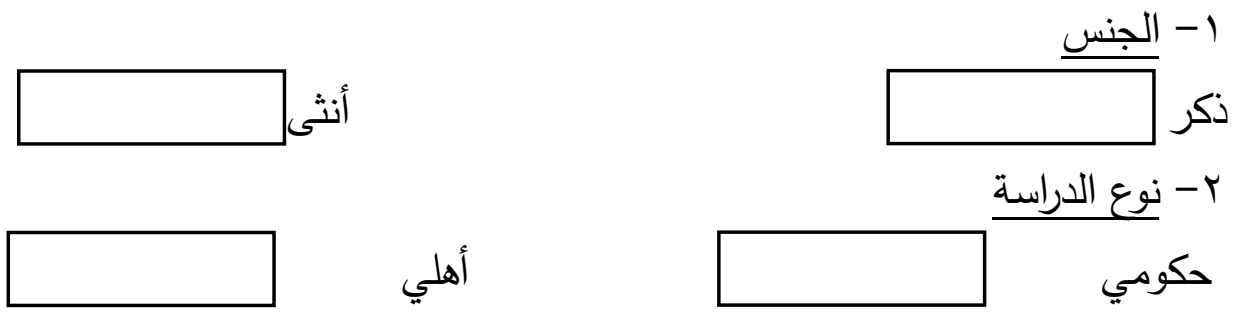

$$
\text { أهلي }
$$$$
\text { r }
$$
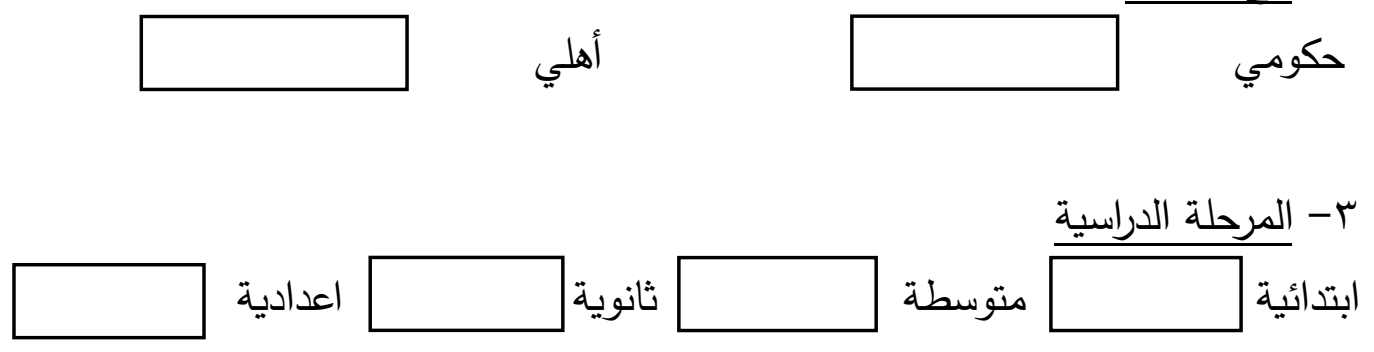
$ه|\varepsilon \varepsilon| / P T \cdot T \cdot$

مجلة الآداب / ملحق العدد זrا ( آذار)

يرجس وضـع إثـارة (X) في الخانـة التي ترونها مناسبة أمسام كل عبـارة مـن العبـارات الآتية

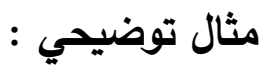

\begin{tabular}{|c|c|c|c|}
\hline متوفرة & غتير متوفيات التعليم & \\
\hline سبورة ذكية & $X$ & & \\
\hline
\end{tabular}

\begin{tabular}{|c|c|c|c|c|}
\hline ت & تقنيات التعليم & لا أعلم & غير متوفرة & متوفرة متوة \\
\hline 1 & سبورة ذكية & & & \\
\hline r & ل ل ابتوب & & & \\
\hline$r$ & مسجل كاسيت & & & \\
\hline$\varepsilon$ & داتا شو Data show & & & \\
\hline 0 & الثاشة الذكية & & & \\
\hline 7 & آلة تصوير & & & \\
\hline$\checkmark$ & انترنيت & & & \\
\hline$\wedge$ & أشرطة سمعية & & & \\
\hline 9 & أشرطة فيديو & & & \\
\hline 1. & مجهر & & & \\
\hline 11 & هاتف ذكي & & & \\
\hline ir & جهاز العارض فوق الرأس & & & \\
\hline
\end{tabular}

تقنيات تعليمية حديثة متوافرة ولم تذكر أعلاه : 


\title{
Educational techniques between reality and ambition (comparative study)
}

\begin{abstract}
:
The aim of the research is to identify the modern educational techniques available in the public and private schools affiliated to the Directorate of Education of Karbala.

In order to verify the research objective, the following questions were formulated:

What are the modern educational techniques available in the public and private schools affiliated to the Department of Education of the Holy Karbala / Center?

1. Are there statistically significant differences at the level of significance (0.05) between the responses of the sample according to gender variable?
\end{abstract}

2. Are there statistically significant differences at the level of significance (0.05) among respondents of the sample according to the variable of the school stage?

3. Are there statistically significant differences at the level of significance (0.05) between the responses of the sample according to the variable type of study?

To answer these questions, a questionnaire consisting of (12) items was directed at a sample of the public and private school administrations in the center of Karbala governorate, which was chosen according to the class method, reaching (141) school administration with (75) managers and (66).

The research reached:

1. The educational techniques available in a large number of public schools are (cassette recorder, camera, microscope), but in private schools (camera, cassette recorder, internet, smart screen)

2. The educational techniques available in a few schools in the government are (Internet, laptop) in the private schools is a (microscope). 
3. There were no statistically significant differences at the level of significance (0.05) between the responses of the sample according to the gender variable.

4. There were no statistically significant differences at the level of significance (0.05) between the responses of the sample according to the variable stage.

5. There were statistically significant differences at the level of significance (0.05) among the responses of the sample according to the type of study variable and in favor of the private schools.

Key Words: Educational techniques, reality, ambition. 